\title{
Safety of betaine as a novel food pursuant to Regulation (EC) No 258/97
}

\author{
EFSA Panel on Dietetic Products, Nutrition and Allergies (NDA), \\ Dominique Turck, Jean-Louis Bresson, Barbara Burlingame, Tara Dean, Susan Fairweather-Tait, \\ Marina Heinonen, Karen Ildico Hirsch-Ernst, Inge Mangelsdorf, Harry ] McArdle, \\ Androniki Naska, Monika Neuhäuser-Berthold, Grażyna Nowicka, Kristina Pentieva, \\ Yolanda Sanz, Alfonso Siani, Anders Sjödin, Martin Stern, Daniel Tomé, Marco Vinceti, \\ Peter Willatts, Karl-Heinz Engel, Rosangela Marchelli, Annette Pöting, Morten Poulsen, \\ Josef Rudolf Schlatter, Emanuela Turla and Henk van Loveren
}

\begin{abstract}
Following a request from the European Commission, the EFSA Panel on Dietetic Products, Nutrition and Allergies (NDA) was asked to deliver an opinion on betaine as a novel food (NF) pursuant to Regulation (EC) No 258/97. The information provided on the composition, the specifications, the batch-to-batch variability, stability and production process of the NF is sufficient and does not raise concerns about the safety of the NF. The NF is proposed to be used in foods intended to meet additional requirements for intense muscular effort with a maximum intake of $2.5 \mathrm{~g} /$ day of betaine for sports people above 10 years of age. Based on the lowest $B M L_{05}$, which was derived from a chronic toxicity study in rats in which a dose-related increase in platelet counts was observed, and the anticipated daily intake of the NF in the target population, the Margins of Exposure are 3.6 and 5, which are generally regarded as not sufficient. However, the total exposure to betaine from the diet (about $830 \mathrm{mg} /$ day) is not known to be associated with adverse effects. Moreover, no adverse effects on platelet counts were noted in human intervention studies with exposure levels of $4 \mathrm{~g} /$ day of betaine for up to 6 months. A significant increase in total and low-density lipoprotein (LDL)-cholesterol concentrations was noted at intakes of $4 \mathrm{~g} /$ day of betaine in overweight subjects with metabolic syndrome but not in healthy subjects, nor at intakes of $3 \mathrm{~g} /$ day. Thus, considering $4 \mathrm{~g} /$ day of betaine as a reference point and applying an uncertainty factor of 10 to account for interindividual variability, an amount of $400 \mathrm{mg} /$ day of betaine (i.e. $6 \mathrm{mg} / \mathrm{kg}$ body weight (bw) per day for adults) in addition to the background exposure is considered as safe. The Panel considers that the NF is safe to be used at maximum intake of $6 \mathrm{mg} / \mathrm{kg}$ bw per day in the target population.
\end{abstract}

(c) 2017 European Food Safety Authority. EFSA Journal published by John Wiley and Sons Ltd on behalf of European Food Safety Authority.

Keywords: betaine, novel food, ingredient, safety

Requestor: European Commission following an application by DuPont Nutritional Biosciences ApS

Question number: EFSA-Q-2016-00287

Correspondence: nda@efsa.europa.eu 
Panel members: Jean-Louis Bresson, Barbara Burlingame, Tara Dean, Susan Fairweather-Tait, Marina Heinonen, Karen Ildico Hirsch-Ernst, Inge Mangelsdorf, Harry J McArdle, Androniki Naska, Monika Neuhäuser-Berthold, Grażyna Nowicka, Kristina Pentieva, Yolanda Sanz, Alfonso Siani, Anders Sjödin, Martin Stern, Daniel Tomé, Dominique Turck, Hendrik Van Loveren, Marco Vinceti and Peter Willatts.

Acknowledgements: The Panel wishes to thank the following for the support provided to this scientific output: José Cortiñas Abrahante.

Amendment: A correction was carried out that does not affect the content or outcome of this scientific output: the maximum safe daily intake level of betaine has been expressed on a $\mathrm{mg} / \mathrm{kg}$ body weight basis. To avoid confusion, the older version has been removed from the EFSA Journal, but is available on request, as is a version showing all the changes made.

Suggested citation: EFSA NDA Panel (EFSA Panel on Dietetic Products, Nutrition and Allergies), Turck D, Bresson J-L, Burlingame B, Dean T, Fairweather-Tait S, Heinonen M, Hirsch-Ernst KI, Mangelsdorf I, McArdle HJ, Naska A, Neuhäuser-Berthold M, Nowicka G, Pentieva K, Sanz Y, Siani A, Sjödin A, Stern M, Tomé D, Vinceti M, Willatts P, Engel K-H, Marchelli R, Pöting A, Poulsen M, Schlatter JR, Turla $E$ and van Loveren $H$, 2017. Scientific opinion on the safety of betaine as a novel food pursuant to Regulation (EC) No 258/97. EFSA Journal 2017;15(11):1, 28 pp. https://doi.org/10.2903/j.efsa.2017. 5057

ISSN: $1831-4732$

(c) 2017 European Food Safety Authority. EFSA Journal published by John Wiley and Sons Ltd on behalf of European Food Safety Authority.

This is an open access article under the terms of the Creative Commons Attribution-NoDerivs License, which permits use and distribution in any medium, provided the original work is properly cited and no modifications or adaptations are made.
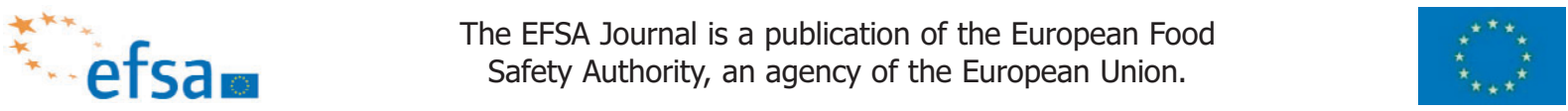


\section{Summary}

Following a request from the European Commission, the EFSA Panel on Dietetic Products, Nutrition and Allergies (NDA) was asked to deliver an opinion on betaine as a novel food (NF) pursuant to Regulation (EC) No 258/97. The assessment, which follows the methodology set in Commission Recommendation $97 / 618 / E C$, is based on the data supplied in the original application, the initial assessment by the competent authority of Finland, the concerns and objections of a scientific nature raised by the other Member States and the responses of the applicant.

The NF is betaine, in anhydrous and monohydrate form, which is obtained from processing of sugar beets (i.e. molasses, vinasses or betaine glycerol). The information provided on the composition, the specifications, the batch-to-batch variability, stability and production process of the NF is sufficient and does not raise concerns about the safety of the NF.

The NF is proposed to be used in foods intended to meet additional requirements for intense muscular effort (i.e. carbohydrate-rich energy food products, carbohydrate-electrolyte solutions, and protein/protein components) with a proposed intake of $2.5 \mathrm{~g}$ betaine per day. The target population proposed by the applicant is sports people above 10 years of age (adolescents and adults). The 95th percentile anticipated intake of the NF is $1.30 \mathrm{~g} /$ day $(26.4 \mathrm{mg} / \mathrm{kg}$ body weight (bw) per day) for adolescents and $2.93 \mathrm{~g} /$ day $(35.7 \mathrm{mg} / \mathrm{kg}$ bw per day) for adults.

Betaine is naturally present in foods, such as beets, spinach and wheat flour. However, betaine exposure from the diet does not only derive from the consumption of betaine-containing foods but also from choline-containing foods as most choline is irreversibly oxidised to betaine in the body. The total exposure to betaine resulting from dietary intake calculated from the sum of highest reported mean intakes across studies can be estimated to be about $830 \mathrm{mg} /$ day.

The available data indicate that, following oral ingestion, betaine is rapidly absorbed, released to the portal circulation and transported to the liver where significant presystemic metabolism occurs. Only a small amount of betaine and its metabolite dimethylglycine are excreted in the urine.

The Panel considers that there is no concern with respect to genotoxicity of the NF.

Several repeated-dose oral toxicity studies with the NF in rodents and piglets have been provided by the applicant, some of which were assessed by the NDA Panel in 2005. At that time, the Panel could not derive a no-observed-adverse effect level (NOAEL) for the NF from the 28-day and 90-day oral toxicity studies.

The applicant has now provided a chronic oral toxicity and carcinogenicity study with the NF. Since an increase in platelet counts in male rats was observed, which is regarded as a critical effect, already occurred at the lowest dose level, the Panel considers that it is not possible to derive a NOAEL for this combined chronic toxicity/carcinogenicity study. Therefore, the data on platelet counts in male rats from the chronic oral toxicity study were subjected to benchmark dose (BMD) modelling. The lowest $\mathrm{BMDL}_{05}$ of $131 \mathrm{mg} / \mathrm{kg}$ bw was considered by the Panel as the reference point (RP) for the risk characterisation. The ratio between this RP and the anticipated daily intake of the NF in adults and adolescents results in Margins of Exposure of 3.6 and 5, which are generally regarded as not sufficient.

However, the Panel notes that the total exposure to betaine resulting from dietary intake calculated from the sum of highest reported mean intakes across studies (about $830 \mathrm{mg} / \mathrm{day}$; i.e. $12 \mathrm{mg} / \mathrm{kg}$ bw per day for adults and up to $19 \mathrm{mg} / \mathrm{kg}$ bw per day for adolescents) is not known to be associated with adverse effects.

Moreover, the Panel notes that four human intervention studies are available with exposure levels of $4 \mathrm{~g} /$ day of betaine supplementation (which corresponds to $57 \mathrm{mg} / \mathrm{kg}$ bw per day for adults) for up to 6 months. In these studies, no adverse effects on platelet counts were noted. The Panel also notes that a significant increase in total and low-density lipoprotein (LDL)-cholesterol concentrations have been reported at intakes of $4 \mathrm{~g} /$ day of betaine in overweight subjects with metabolic syndrome but not in healthy subjects, nor at intakes of $3 \mathrm{~g} /$ day. In this context, the Panel considers that $4 \mathrm{~g} /$ day of betaine can be taken as a RP and that an uncertainty factor of 10 is sufficient to account for interindividual variability. Therefore, an amount of $400 \mathrm{mg} /$ day of betaine (i.e. $6 \mathrm{mg} / \mathrm{kg}$ bw per day by using a mean bw of $70 \mathrm{~kg}$ for adults) in addition to the background exposure is considered as safe.

The Panel concludes that the safety of the NF, betaine, at the intended uses and use levels as proposed by the applicant ( $2.5 \mathrm{~g} / \mathrm{day})$ has not been established.

The Panel considers that the NF is safe to be used at maximum intake of $6 \mathrm{mg} / \mathrm{kg}$ bw per day in the target population (sports people above 10 years of age). 


\section{Table of contents}

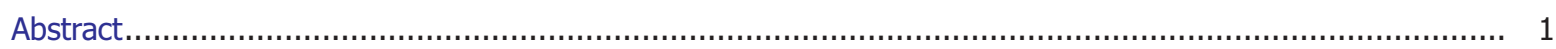

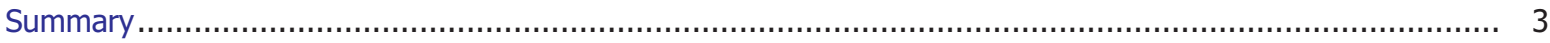

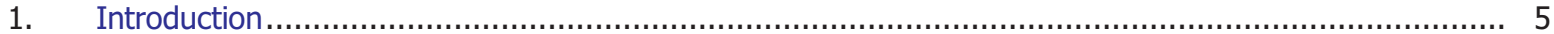

1.1. Background and Terms of Reference as provided by the European Commission ................................ 5

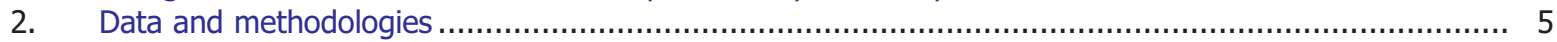

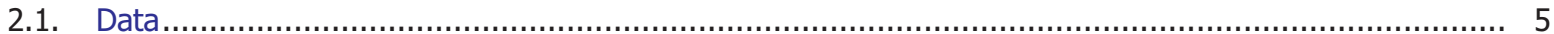

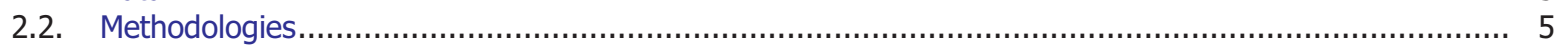

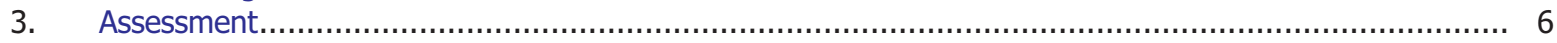

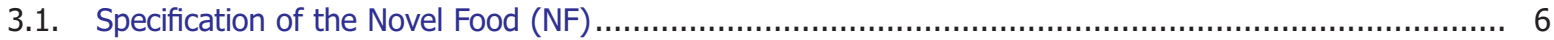

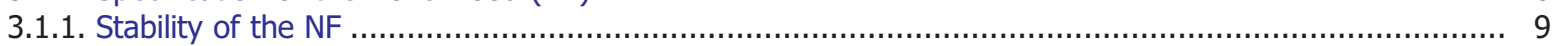

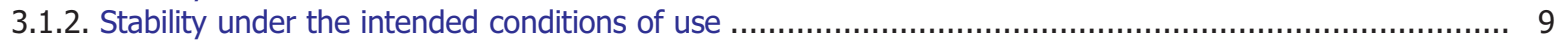

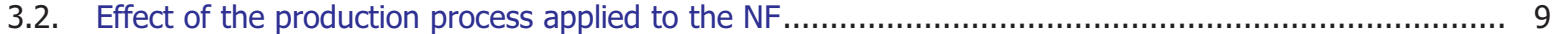

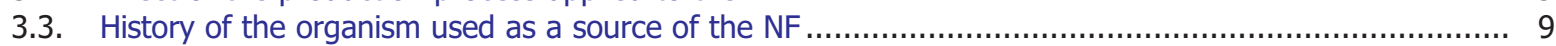

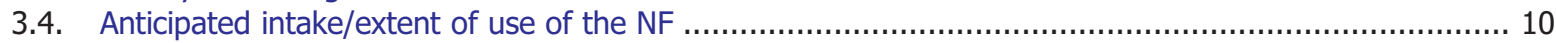

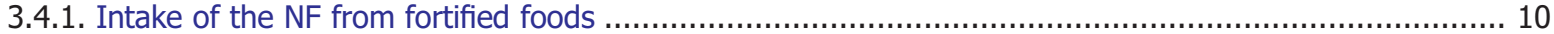

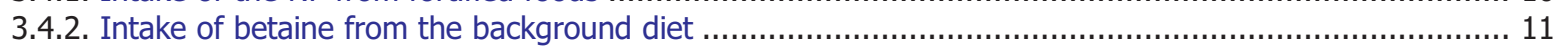

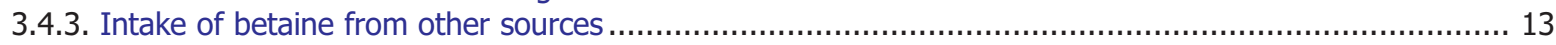

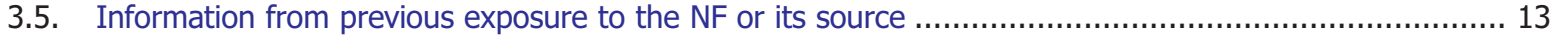

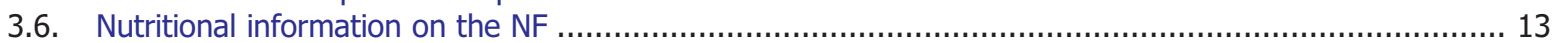

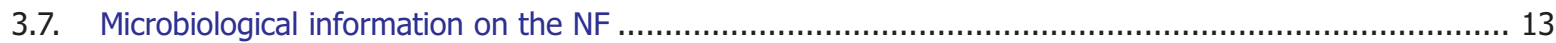

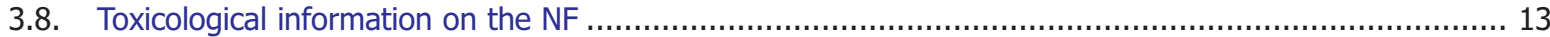

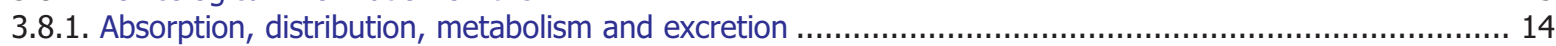

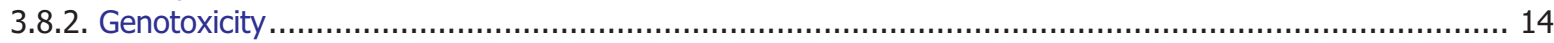

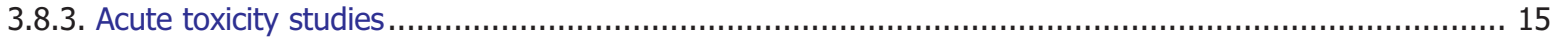

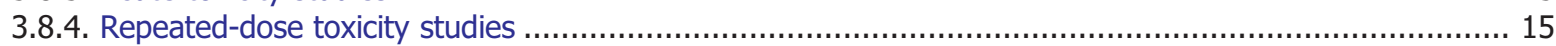

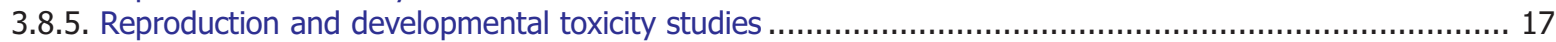

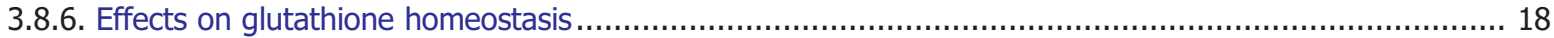

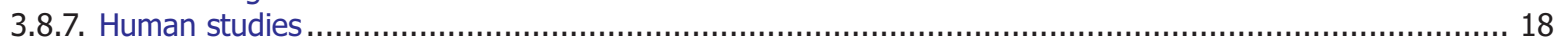

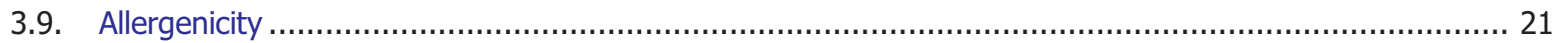

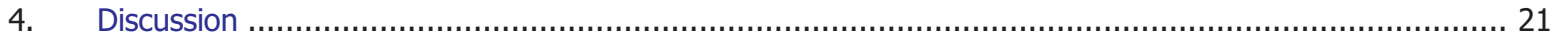

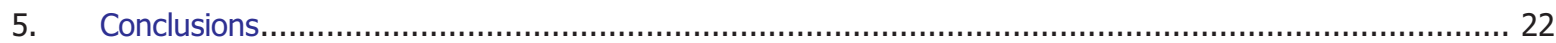

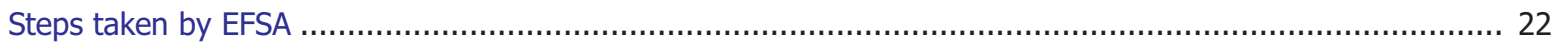

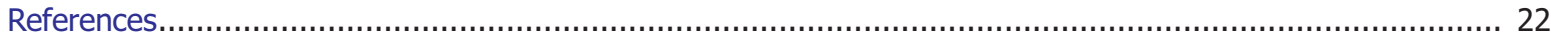

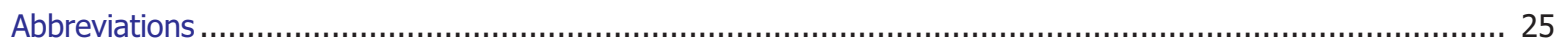

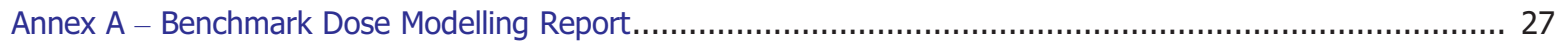




\section{Introduction}

\subsection{Background and Terms of Reference as provided by the European Commission}

On 12 June 2015, the company DuPont Nutritional \& Biosciences ApS submitted a request under Article 4 of the Novel Food Regulation (EC) No $258 / 97^{1}$ to place on the market betaine as a novel food (NF).

On 21 October 2015, the competent authority of Finland forwarded to the Commission its initial assessment report, which came to the conclusion that betaine meets the criteria for acceptance of a NF defined in Article (3)1 of Regulation (EC) No 258/97.

On 23 October 2015, the Commission forwarded the initial assessment report to the other Member States (MS). Several of the MS submitted comments or raised objections.

The concerns of a scientific nature raised by the MS can be summarised as follows:

- Information on whether the laboratories, which carried out the analyses on the NF, were accredited in accordance with internationally recognised systems was missing.

- A MS questioned the no-observed-adverse effect level (NOAEL) proposed by the applicant (i.e. $5 \%$ betaine) for the chronic oral toxicity and carcinogenicity study owing to the observed effects (e.g. decrease in mean corpuscular volume and mean corpuscular haemoglobin, increase in number of platelet counts, decrease in total proteins and albumin concentrations, decrease in albumin/globulin ratio and alkaline phosphatase; increase in liver and kidney weights).

- A MS noted the small margin of exposure between the NF doses at which adverse effects were observed in toxicological studies and the proposed daily intake of the NF.

In accordance with Article 29(1)(a) of Regulation (EC) No 178/2002 ${ }^{2}$, the European Food Safety Authority is asked to carry out the additional assessment for betaine as a NF in the context of Regulation (EC) No 258/97.

EFSA is asked to carry out the additional assessment and to consider the elements of a scientific nature in the comments raised by the other MS.

\section{Data and methodologies}

\subsection{Data}

The assessment of the safety of this NF is based on data supplied in the original application, the initial assessment by the competent authority of Finland, the concerns and objections of a scientific nature raised by the other MS and the responses of the applicant.

In accordance with Commission Recommendation $97 / 618 / \mathrm{EC}_{1}^{3}$ betaine is allocated to Class 1.1 , i.e. 'pure chemicals or simple mixtures from non-GM sources; the source of the NF has a history of food use in the Community'. The data are required to comply with the information required for novel foods of Class 1.1, i.e. structured schemes I, II, III, IX, X, XI, XII and XIII of Commission Recommendation $97 / 618 / E C$. In the current opinion, these structured schemes are listed in Sections 3.1-3.9. The intention is to add the NF to foods for intense muscular effort. This assessment concerns only risks that might be associated with consumption of the NF at the proposed conditions of use, and is not an assessment of the efficacy of betaine with regard to any claimed benefit.

\subsection{Methodologies}

The assessment follows the methodology set out in Commission Recommendation 97/618/EC of 29 July 1997 concerning the scientific aspects and the presentation of information necessary to support applications for the placing on the market of novel foods and novel food ingredients and the

\footnotetext{
${ }^{1}$ Regulation (EC) No 258/97 of the European Parliament and of the Council of 27 January 1997 concerning novel foods and novel food ingredients. OJ L 43, 14.2.1997, p. 1-6.

2 Regulation (EC) No 178/2002 of the European Parliament and of the Council of 28 January 2002 laying down the general principles and requirements of food law, establishing the European Food Safety Authority and laying down procedures in matters of food safety. OJ L 31, 1.2.2002, p. $1-24$

${ }^{3}$ Commission Recommendation 97/618/EC: Commission Recommendation of 29 July 1997 concerning the scientific aspects and the presentation of information necessary to support applications for the placing on the market of novel foods and novel food ingredients and the preparation of initial assessment reports under Regulation (EC) No 258/97 of the European Parliament and of the Council.OJ L 253, 16.9.1997, p. 1-36.
} 
preparation of initial assessment reports under Regulation (EC) No 258/97 of the European Parliament and of the Council.

\section{Assessment}

\subsection{Specification of the Novel Food (NF)}

The NF which is the subject of the application is betaine $(N, N, N$-trimethylglycine or carboxy- $N, N, N$ trimethylmethanaminium), in anhydrous and monohydrate form. The NF is obtained from processing of sugar beets (molasses, vinasses or betaine-glycerol).

The NF is intended to be placed on the market under different brand names (as anhydrous betaine: Betafin $^{\mathrm{TM}}$ BF20, Natural Extract BF, BetaPower ${ }^{\mathrm{TM}}$; as monohydrate betaine: Betafin ${ }^{\mathrm{TM}}$ AF20, Natural Extract AF).

Betaine is naturally present in foods, such as beets, spinach and wheat flour (Patterson et al., 2008).

The chemical formula of the anhydrous form of betaine is $\left(\mathrm{CH}_{3}\right)_{3} \mathrm{~N}^{+} \mathrm{CH}_{2} \mathrm{COO}^{-}$(CAS No: 107-43-7; molecular mass $117.15 \mathrm{Da}$ ), whereas for the monohydrate form it is $\left(\mathrm{CH}_{3}\right)_{3} \mathrm{~N}^{+} \mathrm{CH}_{2} \mathrm{COO}^{-} \cdot \mathrm{H}_{2} \mathrm{O}$ (CAS No: 590-47-6; molecular mass: $135.16 \mathrm{Da}$ ).

The specifications of the NF, which have been revised by the applicant upon EFSA's request, are presented in Table 1. The specifications include physical, chemical and microbiological parameters together with their respective methods of analysis. Composition and purity of the anhydrous and monohydrate forms of betaine are equivalent, with the exception of the water content, which is varied by altering the conditions of the crystallisation phase of the manufacturing process. The specifications of the NF are in line with the standards set by the Food Chemicals Codex (FCC, 2014).

In order to confirm that the manufacturing process is reproducible and adequate to produce a product that is within the specifications as set in Table 1, the applicant provided batch-to-batch analyses of three batches of the NF in its anhydrous and monohydrate form (Table 2).

The NF complies with the current legislation in terms of mycotoxins, dioxins and dioxin-like-PCB (polychlorinated biphenyls), and polycyclic aromatic hydrocarbons. Analyses for pesticides on two batches of betaine (anhydrous form) did not report residues of pesticides, except for Glyfos ${ }^{\circledR}$ which was reported at levels below $0.01 \mathrm{mg} / \mathrm{kg}$. 
Table 1: Specifications of the NF (anhydrous and monohydrate form)

\begin{tabular}{|c|c|c|}
\hline Parameter & Specifications & Method of analysis \\
\hline Physical appearance & Free-flowing white crystals & Visual inspection \\
\hline Colour & Max. 20 & $\begin{array}{l}\text { International Commission for Uniform Methods of Sugar } \\
\text { Analysis (ICUMSA GS2/3-10) }\end{array}$ \\
\hline Betaine & Min. $99 \%$ on dry basis & $\mathrm{HPLC}^{(\mathrm{a})}$ \\
\hline Moisture & $\begin{array}{l}\text { Max. } 2 \% \text { anhydrous } \\
\text { Max. } 15 \% \text { monohydrate }\end{array}$ & $\begin{array}{l}\text { Halogen drying (thermogravimetric method) Internal } \\
\text { Analytical Method 2.10.3.3.-59.3 }\end{array}$ \\
\hline Ash & Max. $0.1 \%$ & Conductometric \\
\hline Chloride & Max. $50 \mathrm{mg} / \mathrm{kg}$ & Dionex Ion chromatography ${ }^{(b)}$ \\
\hline Sulfate & Max. $100 \mathrm{mg} / \mathrm{kg}$ & Dionex Ion chromatography ${ }^{(\mathrm{b})}$ \\
\hline $\mathrm{pH}(5 \%$ solution $)$ & $5-7$ & $\mathrm{pH}$ meter \\
\hline Ethanol & $<10 \mathrm{mg} / \mathrm{kg}$ & HS-GC/MS (in house method accredited by EuroFins) ${ }^{(\mathrm{c})}$ \\
\hline Residual proteins & Max. $1,000 \mu \mathrm{g} / \mathrm{g}$ & $\begin{array}{l}\text { Roti-Nanoquant K880 (Carl Roth } \mathrm{GmbH} \text { ) protein } \\
\text { quantification assay (Modified Bradford protein assay) }{ }^{(\mathrm{d})}\end{array}$ \\
\hline \multicolumn{3}{|l|}{ Heavy metals } \\
\hline Arsenic & $<0.1 \mathrm{mg} / \mathrm{kg}$ & EN 15763:2009, ICP-MS \\
\hline Lead & $<0.05 \mathrm{mg} / \mathrm{kg}$ & EN 15763:2009, ICP-MS \\
\hline Iron & $<0.1 \mathrm{mg} / \mathrm{kg}$ & EN 15763:2009, ICP-MS \\
\hline Cadmium & $<0.01 \mathrm{mg} / \mathrm{kg}$ & EN 15763:2009, ICP-MS \\
\hline Selenium & $<0.2 \mathrm{mg} / \mathrm{kg}$ & EN ISO 17294-2-E29, ICP-MS \\
\hline Mercury & $<0.005 \mathrm{mg} / \mathrm{kg}$ & EN 15763:2009, ICP-MS \\
\hline \multicolumn{3}{|c|}{ Microbiological count } \\
\hline Total viable count & Max $100 \mathrm{cfu} / \mathrm{g}$ & ISO 4833 \\
\hline Yeast & Max $10 \mathrm{cfu} / \mathrm{g}$ & NMKL 98 \\
\hline Mould & Max $10 \mathrm{cfu} / \mathrm{g}$ & NMKL 98 \\
\hline Coliforms & Absent in $10 \mathrm{~g}$ & ISO2152-8 \\
\hline Salmonella & Absent in $25 \mathrm{~g}$ & ISO $2152-8$ \\
\hline
\end{tabular}

cfu: colony forming units; HPLC: high-performance liquid chromatography; ICP-MS: inductively coupled plasma mass spectrometry; HS-GC/MS: headspace gas chromatography/mass spectrometry; ICUMSA: International Commission for Uniform Methods of Sugar Analysis.

Limits of detection: (a) $5 \mathrm{mg} / \mathrm{kg}$; (b) $<5 \mathrm{mg} / \mathrm{kg}$; (c) $<10 \mathrm{mg} / \mathrm{kg}$; (d) $25 \mu \mathrm{g} / \mathrm{g}$. 
Table 2: Batch-to-batch analyses of the NF (anhydrous and monohydrate forms)

\begin{tabular}{|c|c|c|c|c|c|c|c|}
\hline \multirow[b]{2}{*}{ Parameter } & \multirow[b]{2}{*}{ Specifications } & \multicolumn{3}{|c|}{ Analytical data for anhydrous betaine } & \multicolumn{3}{|c|}{ Analytical data for monohydrate betaine } \\
\hline & & $\begin{array}{l}\text { Batch } \\
4311946923\end{array}$ & $\begin{array}{l}\text { Batch } \\
4311782722 \\
\end{array}$ & $\begin{array}{l}\text { Batch } \\
\mathbf{4 3 1 2 3 0 5 3 7 8 6}\end{array}$ & $\begin{array}{l}\text { Batch } \\
4311788559\end{array}$ & $\begin{array}{l}\text { Batch } \\
4312102070\end{array}$ & $\begin{array}{l}\text { Batch } \\
4312255008\end{array}$ \\
\hline Physical appearance & $\begin{array}{l}\text { Free-flowing } \\
\text { white crystals }\end{array}$ & $\begin{array}{l}\text { Conforms to } \\
\text { specification }\end{array}$ & $\begin{array}{l}\text { Conforms to } \\
\text { specification }\end{array}$ & $\begin{array}{l}\text { Conforms to } \\
\text { specification }\end{array}$ & $\begin{array}{l}\text { Conforms to } \\
\text { specification }\end{array}$ & $\begin{array}{l}\text { Conforms to } \\
\text { specification }\end{array}$ & $\begin{array}{l}\text { Conforms to } \\
\text { specification }\end{array}$ \\
\hline Colour & Max. 20 & 2 & 0 & 0 & 0 & 4 & 1 \\
\hline Betaine & $\begin{array}{l}\text { Min. } 99 \% \text { (w/w on } \\
\text { dry weight basis) }\end{array}$ & 99.6 & 99.2 & 100.0 & 99.1 & 99.3 & 99.8 \\
\hline Moisture & $\begin{array}{l}\text { Max. } 2 \% \mathrm{w} / \mathrm{w} \\
\text { anhydrous } \\
\text { Max. } 15 \% \mathrm{w} / \mathrm{w} \\
\text { monohydrate }\end{array}$ & 0.8 & 0.8 & 0.7 & 13 & 13.2 & 13.4 \\
\hline Ash & Max. $0.1 \% \mathrm{w} / \mathrm{w}$ & 0.0027 & 0.0032 & 0.0017 & 0.0025 & 0.0056 & 0.0032 \\
\hline Chloride & Max. $50 \mathrm{mg} / \mathrm{kg}$ & 4 & 7 & 3 & 5 & 5 & 9 \\
\hline Sulfate & Max. $100 \mathrm{mg} / \mathrm{kg}$ & 10 & 2 & 3 & 5 & 4 & 10 \\
\hline $\mathrm{pH}(5 \%$ solution) & $5-7$ & 6.7 & 6.5 & 6.6 & 6.5 & 6.6 & 6.6 \\
\hline Ethanol & $<10 \mathrm{mg} / \mathrm{kg}$ & $\begin{array}{l}<10 \text { (Batch } \\
4311989522)\end{array}$ & $\begin{array}{l}<10 \text { (Batch } \\
4311991121)\end{array}$ & $\begin{array}{l}<10 \text { (Batch } \\
4312437848)\end{array}$ & - & - & - \\
\hline Residual proteins & $<1,000 \mu \mathrm{g} / \mathrm{g}$ & $\begin{array}{l}220 \text { (Batch } \\
4312920393)\end{array}$ & $\begin{array}{l}240 \text { (Batch } \\
4312878054)\end{array}$ & $\begin{array}{l}220 \text { (Batch } \\
4312614128)\end{array}$ & & & \\
\hline Arsenic & $<0.1 \mathrm{mg} / \mathrm{kg}$ & $<0.1^{*}$ & $<0.1^{*}$ & $<0.1^{*}$ & $<0.1^{*}$ & $<0.1 *$ & $<0.1^{*}$ \\
\hline Lead & $<0.05 \mathrm{mg} / \mathrm{kg}$ & $<0.05^{*}$ & $<0.05^{*}$ & $<0.05^{*}$ & $<0.05^{*}$ & $<0.05^{*}$ & $<0.05^{*}$ \\
\hline Iron & $<0.1 \mathrm{mg} / \mathrm{kg}$ & $<0.1^{*}$ & $<0.1^{*}$ & $<0.1^{*}$ & $<0.1^{*}$ & $<0.1^{*}$ & $<0.1^{*}$ \\
\hline Cadmium & $<0.01 \mathrm{mg} / \mathrm{kg}$ & $\begin{array}{l}<0.01 * \text { (Batch } \\
4312158590)\end{array}$ & $\begin{array}{l}<0.01 * \text { (Batch } \\
4312346281)\end{array}$ & $\begin{array}{l}<0.01 * \text { (Batch } \\
4311527904)\end{array}$ & - & - & - \\
\hline Selenium & $<0.2 \mathrm{mg} / \mathrm{kg}$ & $\begin{array}{l}<0.2 * \text { (Batch } \\
4312158590)\end{array}$ & $\begin{array}{l}<0.2^{*} \text { (Batch } \\
4312346281)\end{array}$ & $\begin{array}{l}<0.2 * \text { (Batch } \\
4311527904)\end{array}$ & - & - & - \\
\hline Mercury & $<0.005 \mathrm{mg} / \mathrm{kg}$ & $\begin{array}{l}<0.005 * \text { (Batch } \\
4312158590)\end{array}$ & $\begin{array}{l}<0.005^{*} \text { (Batch } \\
4312346281)\end{array}$ & $\begin{array}{l}<0.005^{*} \text { (Batch } \\
4311527904)\end{array}$ & - & - & - \\
\hline Total viable count & Max $100 \mathrm{cfu} / \mathrm{g}$ & $<100$ & $<100$ & $<100$ & $<100$ & $<100$ & $<100$ \\
\hline Yeast & Max $10 \mathrm{cfu} / \mathrm{g}$ & $<10$ & $<10$ & $<10$ & $<10$ & $<10$ & $<10$ \\
\hline Mould & Max $10 \mathrm{cfu} / \mathrm{g}$ & $<10$ & $<10$ & $<10$ & $<10$ & $<10$ & $<10$ \\
\hline Coliforms & Absent in $10 \mathrm{~g}$ & Absent & Absent & Absent & Absent & $<10$ & $<10$ \\
\hline Salmonella & Absent in $25 \mathrm{~g}$ & Absent & Absent & Absent & Absent & $<10$ & $<10$ \\
\hline
\end{tabular}


One of the two test facilities, in which the analyses were carried out, was accredited in accordance to ISO 17025 standard, whereas the other one was certified in accordance to ISO 9001:2008 and ISO 14001:2004.

The Panel considers that the information provided on the composition, the specifications and the batch-to-batch variability of the NF is sufficient and does not raise safety concerns.

\subsubsection{Stability of the NF}

The applicant provided the results from stability tests performed with three batches of the NF (anhydrous and monohydrate form) in the original packaging (carton with a polyethylene inner bag) and stored at $15-25^{\circ} \mathrm{C}$ over a period of 40 months. These data show that the NF remains within the specifications, with the exception of the moisture content for one batch of anhydrous betaine which slightly exceeded the specified limit after 40 months ( $2.1 \%$ vs $2 \%)$. Based on these data, the applicant proposed a shelf-life of 36 months for the NF (anhydrous and monohydrate form) when stored in the unopened original packaging (cartons with a polyethylene inner bag) and protected from humidity. NF.

The Panel considers that the data provided sufficient information with respect to the stability of the

\subsubsection{Stability under the intended conditions of use}

The stability of the $\mathrm{NF}$, when used as an ingredient in isotonic ready-to-drink beverages (noncarbonated), has been investigated in two formulations at different $\mathrm{pH}$ (pH 3 and $\mathrm{pH} 4$, respectively).

The two formulations were stored at $20^{\circ} \mathrm{C}$ or $35^{\circ} \mathrm{C}$, in light or dark conditions, for up to 12 months, and tested for betaine content (by liquid chromatography/electrospray ionisation-isotope dilution mass spectrometry (LC/ESI-IDMS)) at different time points (3, 6, 9 and 12 months).

This study reported a maximum loss of betaine of $10 \%$ after 12 months. Based on these results and the stability of the NF over 40 months, the applicant does not expect to see a significant loss of betaine content in beverages.

The Panel considers that the data provided sufficient information with respect to the stability of the NF under the intended conditions of use.

\subsection{Effect of the production process applied to the NF}

Betaine is extracted with hot water from either: (i) non-genetically modified (GM) sugar beet molasses (the syrupy by-product obtained from sugar refining of sugar beets), (ii) non-GM sugar beet vinasses (the by-product obtained from fermentation where molasses are used as a carbon source) using Saccharomyces cerevisiae (baker's yeast) or (iii) betaine-glycerol (the product obtained by further separation/purification of non-GM sugar beet vinasses). After several chromatographic purification steps, betaine can be crystallised either as the anhydrous or monohydrate form by adjusting the conditions of the crystallisation.

Upon EFSA's request, the applicant provided a detailed description of the steps applied to produce vinasses and betaine-glycerol from beet molasses.

Upon EFSA's request, the applicant indicated the control steps (e.g. microfiltration) which are in place to ensure that $S$. cerevisiae is removed from the final product.

The NF (anhydrous and monohydrate form) is produced in accordance with Good Manufacturing Practices and Hazard Analysis and Critical Control Points principles. The quality controls in place at the manufacturing site are certified by Lloyd's Register Quality Assurance, Evira as well as by the Local Health Authority periodically conducting a review.

The Panel considers that the production process is sufficiently described and does not raise safety concerns.

\subsection{History of the organism used as a source of the NF}

Betaine is produced from sugar beet (Beta vulgaris L.), which belongs to the Amaranthaceae family.

Sugar beet originates from Asia and grows in temperate regions in Europe and North America. Sugar beet is mainly used for sugar production. Sugar beet are planted in spring and harvested in autumn. In the initial growing period, sugar is accumulated in the leaves for the plant growth processes, whereas in the late growing period sugar is accumulated in the roots. Typically, sugar beet roots consist of $75.9 \%$ water, $18 \%$ sugars, $2.6 \%$ non-sugar components and $5.5 \%$ pulp (FAO, 1994, 2013; CFIA, 2012). 
Sugar beet has a long history of use as a food ingredient, in particular as a source of sweets among the Egyptians, Indians, Chinese, Greeks and Romans (Deerr, 1950).

Products derived from sugar beets (e.g. sugar, fibre, syrups) are currently used as foods or food ingredients or ingredients in animal feeding in Europe and in the USA.

The applicant indicated that sugar beet syrups, which contain up to $3 \%$ of betaine, have been sold in Europe prior to 1997.

\subsection{Anticipated intake/extent of use of the NF}

The NF is proposed to be used in foods intended to meet additional requirements for intense muscular effort: carbohydrate-rich energy food products, carbohydrate-electrolyte solutions, and protein/protein components. The composition of these foods is described in the report on 'foods intended to meet the expenditure of intense muscular effort' by the Scientific Committee on Food (SCF, 2001).

The proposed intake of betaine is $2.5 \mathrm{~g} /$ day. Proposed food uses and maximum use levels of the NF are presented in Table 3.

The applicant indicated that foods added with the NF will be packaged in single portion sizes with labelling indications on the amount of betaine per serving $(1.25 \mathrm{~g})$ and the recommended daily intake ( $2.5 \mathrm{~g}$ betaine per day).

The target population proposed by the applicant is sports people above 10 years of age (adolescents and adults).

The applicant indicated that betaine fortified foods may replace betaine food supplements in sports people.

Table 3: Proposed uses and maximum use levels of the NF

\begin{tabular}{l|l|c|l|l}
\hline $\begin{array}{l}\text { EFSA Food } \\
\text { classification system }\end{array}$ & Proposed uses & $\begin{array}{c}\text { NF per } \\
\text { serving (g) }\end{array}$ & $\begin{array}{l}\text { Typical serving } \\
\text { size (g) }\end{array}$ & $\begin{array}{l}\text { Maximum use level of the } \\
\text { NF (g per 100 g of food) }\end{array}$ \\
\hline $\begin{array}{l}\text { Carbohydrate-rich } \\
\text { energy food products }\end{array}$ & Cereal bars & 1.25 & 60 & 2.1 \\
\cline { 2 - 5 } & $\begin{array}{l}\text { Carbohydrate-rich } \\
\text { drink powders }\end{array}$ & 1.25 & $\begin{array}{l}15-20 \mathrm{~g} \text { (powder); } \\
250-500 \text { (RTD) }\end{array}$ & $\begin{array}{l}6.3-8.3 \text { (powder); } \\
0.25-0.5 \text { (RTD) }\end{array}$ \\
\hline $\begin{array}{l}\text { Carbohydrate- } \\
\text { electrolyte solutions }\end{array}$ & $\begin{array}{l}\text { Isotonic ready-to- } \\
\text { drink beverages } \\
\text { (non-carbonated) }\end{array}$ & 1.25 & 500 & 0.25 \\
\hline $\begin{array}{l}\text { Protein and protein } \\
\text { components }\end{array}$ & Protein bars & 1.25 & 60 & 2.1 \\
\cline { 2 - 5 } & Protein-rich drink & 1.25 & $\begin{array}{l}15-20 \mathrm{~g} \text { (powder); } \\
250-500 \text { (RTD) }\end{array}$ & $\begin{array}{l}6.3-8.3 \text { (powder); } \\
0.25-0.5 \text { (RTD) }\end{array}$ \\
\hline
\end{tabular}

NF: novel food; RTD: ready-to-drink.

(a): Serving size and proposed use per made-up (RTD) beverage and based on manufacturers information on typical UK products.

\subsubsection{Intake of the NF from fortified foods}

In a tiered approach, the applicant provided estimates of the anticipated intake of the NF based on the summary statistics from the EFSA Comprehensive European Food Consumption Database which generally leads to an overestimation of anticipated daily intakes.

For a refined intake estimate of the NF, the applicant used individual data from the UK National Diet and Nutrition Survey (NDNS) Rolling Survey Programme covering the period 2008-2011 for teenagers and adults (NDNS, 2012).

In the absence of specific foods for sports people within the UK food categorisation system, specific food categories were selected to represent the foods to which the NF is intended to be added. The 'representative' food categories and use levels which were used to estimate the anticipated daily intake of the NF are presented in Table 4. 
Table 4: UK food categories and NF use levels which were used to estimate the intake of the NF from the UK NDNS Survey Data

\begin{tabular}{|c|c|c|c|c|}
\hline UK food categories & & $\begin{array}{c}\text { NF per } \\
\text { serving }(g)\end{array}$ & $\begin{array}{l}\text { Serving } \\
\text { size }(g)\end{array}$ & $\begin{array}{l}\text { NF use level }(\mathrm{g} \text { of } \\
\text { NF per } 100 \mathrm{~g})\end{array}$ \\
\hline \multirow[t]{2}{*}{ Flavoured beverages } & Drink powders $^{(a)}$ & 1.25 & 500 & 0.25 \\
\hline & $\begin{array}{l}\text { Isotonic ready-to-drink } \\
\text { beverages }\end{array}$ & 1.25 & 500 & 0.25 \\
\hline \multirow{2}{*}{$\begin{array}{l}\text { Foods intended for particular } \\
\text { nutritional uses }\end{array}$} & Protein or cereal bars & 1.25 & 60 & 2.1 \\
\hline & $\begin{array}{l}\text { Meal replacement } \\
\text { beverages }\end{array}$ & 1.25 & 250 & 0.5 \\
\hline
\end{tabular}

NF: novel food.

(a): Serving size and proposed use levels is per made up beverage; serving sizes are based on typical servings of beverages or meal replacement bars in the UK based on manufacturers' information.

Based on the UK food categories indicated in Table 4 and the food consumption data from the UK NDNS Rolling Survey Programme (2008-2011), the mean and 95th percentile anticipated daily intake of the NF for teenagers and adults have been calculated (Tables 5 and 6 , on a $\mathrm{g}$ and on a $\mathrm{mg} / \mathrm{kg}$ body weight (bw) basis, respectively).

The 95th percentile anticipated daily intake of the NF is $1.30 \mathrm{~g}(26.4 \mathrm{mg} / \mathrm{kg} \mathrm{bw})$ for teenagers and $2.93 \mathrm{~g}(35.7 \mathrm{mg} / \mathrm{kg} \mathrm{bw})$ for adults.

Information on the contribution of each food category selected from the UK NDNS Survey (Table 4) to the total anticipated daily intake of the NF was provided by the applicant: in adolescents, isotonic drinks would contribute to $70-81 \%$, meal replacement beverages to $12-31 \%$ and drink powders to $7 \%$; in adults, drink powders would contribute to $48-51 \%$, isotonic drinks to $7-46 \%$, meal replacement to $1-33 \%$ and protein/cereal bars to $6-9 \%$.

Table 5: Estimate of the anticipated daily intake of the NF ( $g /$ day) from the UK NDNS Data (population of consumers only)

\begin{tabular}{|l|c|c|c|c}
\hline Population group & $\begin{array}{c}\text { \% of } \\
\text { consumers }\end{array}$ & $\begin{array}{c}\text { N of } \\
\text { consumers }\end{array}$ & $\begin{array}{c}\text { Mean } \\
\text { (g/day) }\end{array}$ & $\begin{array}{c}\text { 95th } \\
\text { Percentile (g/day) }\end{array}$ \\
\hline All teenagers (11-18 years old) & 8.5 & 56 & 0.59 & 1.30 \\
\hline All adults (19-64 years old) & 3.8 & 43 & 0.89 & 2.93 \\
\hline
\end{tabular}

Table 6: Estimate of the anticipated daily intake of the NF ( $\mathrm{mg} / \mathrm{kg}$ bw per day) from the UK NDNS Data (population of consumers only)

\begin{tabular}{l|c|c|c|c}
\hline Population group & $\begin{array}{c}\text { \% of } \\
\text { consumers }\end{array}$ & $\begin{array}{c}\text { N of } \\
\text { consumers }\end{array}$ & $\begin{array}{c}\text { Mean (mg/kg bw } \\
\text { per day) }\end{array}$ & $\begin{array}{c}\text { 95th Percentile } \\
\text { (mg/kg bw per day) }\end{array}$ \\
\hline All teenagers (11-18 years old) & 8.5 & 56 & 9.6 & 26.4 \\
\hline All adults (19-64 years old) & 3.8 & 43 & 10.6 & 35.7 \\
\hline
\end{tabular}

The applicant also provided two reports on the market and consumer's attitude towards sports nutrition products in Norway, Sweden and Denmark (Ånestad et al., 2009; Schjøll et al., 2009). The Panel considers that these reports do not provide information on the estimated intake of the NF from fortified foods.

\subsubsection{Intake of betaine from the background diet}

In the previous opinion on the safety of betaine as a NF (EFSA, 2005), the intake of betaine from the background diet was reported to range from about $500 \mathrm{mg} /$ day (average) to $2.5 \mathrm{~g} /$ day for a high seafood diet. The high intake of $2.5 \mathrm{~g} /$ day was reported in a review article on 'betaine in human nutrition' by Craig (2004). This estimate was based on the betaine content in foods reported by Zeisel et al. (2003) and an unpublished exposure assessment referred to by Craig (2004). A similar range (i.e. $0.5-2.0 \mathrm{~g} /$ day) was also indicated in the EFSA health claim opinion on betaine in 2011 (EFSA NDA Panel, 2011). 
The present application provides a revised intake estimate of betaine from the background diet on the basis of more recent data from the United States Department of Agriculture (USDA) database (Patterson et al., 2008). In the report by Patterson et al. (2008), the betaine content in some foods (e.g. seafood and spinach) was reduced as compared to the previous version of the USDA database (Howe et al., 2004) and the levels previously reported by Zeisel et al. (2003) owing to a technical problem in the analysis which led to an overestimation of the betaine content in some foods.

According to Patterson et al. (2008), betaine content is highest in quinoa $(630 \mathrm{mg} / 100 \mathrm{~g})$, followed by ready-to-eat breakfast-cereals (up to $360 \mathrm{mg} / 100 \mathrm{~g}$ ), beets and spinach $(120 \mathrm{mg} / 100 \mathrm{~g}$ ), wheat bread $(85 \mathrm{mg} / 100 \mathrm{~g})$, spaghetti $(68 \mathrm{mg} / 100 \mathrm{~g})$, snacks $(50 \mathrm{mg} / 100 \mathrm{~g})$, white bread and chicken (30 mg/100 g).

The applicant has also provided several studies on the dietary intake of betaine in adults, the majority of which was conducted outside Europe, except for the studies by Detopoulou et al. (2008), Dalmeijer et al. (2008) and Price et al. (2010).

In Greek adults, Detopoulou et al. (2008) reported mean betaine intakes of $306 \mathrm{mg} / \mathrm{day}$ in men $(n=1,514)$ and $314 \mathrm{mg} /$ day in women $(n=1,528)$ who participated in the ATTICA survey. Dietary intake was assessed through a validated semi-quantitative food-frequency questionnaire. Dalmeijer et al. (2008) reported mean betaine intakes of $241 \mathrm{mg} /$ day in 16,165 Dutch women who participated in the European Prospective Investigation into Cancer and Nutrition cohort study. Dietary intake was assessed with a food-frequency questionnaire. In these studies, the betaine content in foods was based on the 2004 USDA database (Howe et al., 2004).

In the intervention study by Price et al. (2010) in Northern Ireland in 79 adults, a mean betaine intake of $127 \mathrm{mg} /$ day was reported through 4-day food diaries. The betaine content in foods was based on the USDA database by Patterson et al. (2008).

Among the remaining studies provided, which were conducted outside Europe, Ross et al. (2014) presented the results on betaine intakes from 17 studies in which the data on betaine content in foods were adjusted when the 2004 USDA database was used. Among these studies the mean intake of betaine ranged from 70 to $154 \mathrm{mg} /$ day, with median betaine intakes ranging from 40 to $298 \mathrm{mg} /$ day.

Mygind et al. (2013) reported a mean betaine intake of $178 \mathrm{mg} /$ day and a 95th percentile of $300 \mathrm{mg} /$ day in $125 \mathrm{New}$ Zealander women. Dietary intake was assessed through a 3-day weighed food record and the betaine content in foods was based on the USDA database by Patterson et al. (2008).

Studies in USA and China reported mean betaine intakes up to around $220 \mathrm{mg} /$ day (Shaw et al., 2004; Fischer et al., 2005) and $310 \mathrm{mg} /$ day (Zeng et al., 2014; Zhang et al., 2013). Dietary intakes were assessed through a 3-day food record, or food-frequency questionnaires, and the betaine content in foods was based on the database by Zeisel et al. (2003).

Overall, the mean betaine intake estimate from the background diet ranges approximately between 70 and $300 \mathrm{mg} /$ day across the studies. On this basis, the Panel notes that the mean betaine daily intake estimate from the background diet is at least eight times lower than the maximum intended daily intake of the NF from fortified foods ( $2.5 \mathrm{~g} /$ day).

However, betaine exposure from the diet does not only derive from the consumption of betainecontaining foods but also from choline-containing foods as most choline is irreversibly oxidised to betaine in the body.

As reported in the EFSA opinion on Dietary Reference Value on choline (EFSA NDA Panel, 2016), the mean choline intake estimates in adults ranged from 269 to $468 \mathrm{mg} /$ day from national surveys in seven EU countries (Vennemann et al., 2015), and were between 265 and $415 \mathrm{mg} /$ day in three studies conducted in non-EU countries (Chu et al., 2012; USDA, 2012; Mygind et al., 2013). That opinion also reported that in children aged 10-17 years, the choline intake estimate ranged between 244 and $373 \mathrm{mg} /$ day based on seven surveys in EU countries.

Publications on choline intake estimates were provided by the applicant (FASEB, 1981; Zeisel, 1981; USDA, 2010; Mygind et al., 2013).

Based on the data above, the mean choline intake estimate from the background diet ranges between 269 and $468 \mathrm{mg} /$ day. Assuming that all dietary choline is ultimately oxidised to betaine, the mean exposure to betaine would range between 302 and $526 \mathrm{mg} /$ day by considering the molecular weight of betaine and choline.

The total exposure to betaine resulting from dietary intake calculated from the sum of highest reported mean intakes across the studies (i.e. $300 \mathrm{mg} /$ day from betaine-containing foods and $526 \mathrm{mg} /$ day from choline-containing foods) can be estimated to be about $830 \mathrm{mg} / \mathrm{day}$. The Panel notes that the background exposure to betaine from the diet is at least 3 times lower than the maximum intended daily intake of the NF from fortified foods $(2.5 \mathrm{~g} /$ day $)$. 


\subsubsection{Intake of betaine from other sources}

The applicant indicated that betaine-containing food supplements (serving size about $1.2-1.5 \mathrm{~g}$ betaine) are currently available in the EU market and are used by sports people. The applicant indicated that the proposed uses of the NF (i.e. foods intended to meet additional requirements for intense muscular effort) will partially or wholly replace betaine-containing food supplements.

Anhydrous betaine is used as a medicine for the treatment of a rare disease, homocystinuria, at daily doses of $100 \mathrm{mg} / \mathrm{kg}$ bw (EMA, 2007).

\subsection{Information from previous exposure to the NF or its source}

Information from previous exposure to the NF or its source is provided in Sections 3.3 and 3.4.

\subsection{Nutritional information on the NF}

Betaine is a natural component in a variety of foods (see Section 3.4.2). Betaine is also produced in the human body through the irreversible oxidation of free choline in the liver and kidneys, and it acts as a methyl donor in the methionine cycle (see Section 3.8.1).

Serum vitamin $B_{12}$, folate and plasma vitamin $B_{6}$ concentrations were assessed in healthy individuals in studies on the effect of betaine supplementation on plasma homocysteine concentrations (Schwab et al., 2002, 2011; Steenge et al., 2003; Olthof et al., 2006). Steenge et al. (2003) reported a statistically significant increase in serum vitamin $B_{12}$ concentrations following intake of $6 \mathrm{~g} /$ day of betaine for 6 weeks. However, the authors attributed this effect to a reduction in serum vitamin $B_{12}$ concentrations in the placebo group which was mainly due to a substantial drop in one subject. Apart from this effect reported by Steenge et al. (2003), no significant differences in these vitamin concentrations were observed at betaine intakes of $6 \mathrm{~g} /$ day for 6 weeks up to $4 \mathrm{~g} /$ day for 6 months as compared to the placebo group (Schwab et al., 2002, 2011; Steenge et al., 2003; Olthof et al., 2006).

In a kinetic study on $\mathrm{L}-\left[{ }^{2} \mathrm{H}_{3}\right.$-methyl- $\left.-1-{ }^{13} \mathrm{C}\right]$ methionine metabolism in healthy young adult men, betaine supplementation of $3 \mathrm{~g} /$ day for 4 days significantly increased not only plasma methionine concentrations, but also the rate of methionine utilisation via transmethylation as well as the rate of methionine oxidation (Storch et al., 1991). The increased rate of methionine oxidation measured in this study was equivalent to $30 \%$ of the dietary methionine intake and the total rate of methionine oxidation was essentially equivalent to the total intake of methionine during the intervention period. Based on these results, Storch et al. (1991) hypothesised that excess intake of betaine may increase the dietary requirement for methionine, but simultaneously pointed out that subjects were not studied during the fasting or post-absorptive phase of amino acid metabolism, and therefore, an effect prior to betaine supplementation at an early post-absorptive period or at a total over a 24-h period could not be ruled out. In another study in healthy men and women ingesting $6 \mathrm{~g} /$ day of betaine for 6 weeks, methionine concentrations were higher compared to the placebo group both in fasting plasma and after methionine loading (Olthof et al., 2003) which supports the hypothesis that betaine is available as methyl donor (Schwahn et al., 2003) for the remethylation of homocysteine to methionine. Based on available studies, the Panel notes that the overall impact of betaine on methionine requirement has not been demonstrated.

The Panel considers that consumption of the NF is not nutritionally disadvantageous.

\subsection{Microbiological information on the NF}

To ensure the absence of microorganisms, the NF is tested for yeasts, moulds, coliforms and Salmonella spp. as described in the specifications (Table 1). The results of analyses for microorganisms in three batches of the NF are presented in Table 2.

The Panel considers that the microbiological information provided does not raise safety concerns.

\subsection{Toxicological information on the NF}

The safety of betaine as a NF was evaluated by the NDA Panel in 2005 (EFSA, 2005). Since the finalisation of that evaluation, new data on the safety of the NF have become available and have been provided by the applicant in the context of the current NF application. 


\subsubsection{Absorption, distribution, metabolism and excretion}

Information on kinetics and metabolism of betaine has been previously assessed by the Panel (EFSA, 2005).

In the context of the current application, the applicant provided a new study on the kinetics and metabolism of betaine (Schwab et al., 2006). Using a randomised, double-blind, cross-over design, healthy volunteers (three men and seven women) were administered single doses of 1,3 and $6 \mathrm{~g}$ betaine in orange juice. Blood samples were taken up to $24 \mathrm{~h}$ after administration, and the 24-h urine was collected. The levels of betaine and its metabolite dimethylglycine (DMG) were determined in plasma and urine. Orally administered betaine had an immediate and dose-dependent effect on serum betaine concentration. Maximum concentrations $\left(C_{\max }\right)$ were reached 40,60 and 80 min $\left(T_{\max }\right)$ after administration of 1,3 and $6 \mathrm{~g}$, respectively. Betaine was rapidly absorbed with $T_{1 / 2 a b s}$ between 11 and $23 \mathrm{~min}$ and $T_{1 / 2 \text { dist }}$ between 28 and $49 \mathrm{~min}$, and elimination occurred with $T_{1 / 2 \text { elim }}$ between 7.5 and $8.8 \mathrm{~h}$. A small proportion of ingested betaine was excreted via urine during $24 \mathrm{~h}$; the calculated sum of betaine and its first metabolite DMG in urine was 3.2\%, $4.3 \%$ and $7.4 \%$ of the ingested amount of 1,3 and $6 \mathrm{~g}$ betaine, respectively. The kinetic parameters reported by Schwab et al. (2006) are largely consistent with those observed in the study by Schwahn et al. (2003), which was assessed by the Panel in 2005 (EFSA, 2005), with the exception of the elimination half-life ( $\left.T_{1 / 2 \text { elim }}\right)$ of betaine which is shorter in the study by Schwab et al. (2006) as compared to the study by Schwahn et al. (2003) (7.5-8.8 h vs $14.4 \mathrm{~h}$, respectively).

Four randomised, placebo-controlled, double-blind human intervention studies reported plasma and/or urine levels of betaine and/or its metabolite DMG following supplementation of betaine at doses up to $6 \mathrm{~g}$ over periods up to 6 months (Schwab et al., 2002, 2011; unpublished study report, undated; Tiihonen et al., 2016). The description of these human intervention studies is provided in Section 3.8.7.

Schwab et al. (2002) reported that betaine supplementation of $6 \mathrm{~g} /$ day for 12 weeks induced a $>10$-fold increase in plasma betaine concentrations from the normal range of about $20 \mu \mathrm{mol} / \mathrm{L}$.

Schwab et al. (2011) reported that 6 months of $4 \mathrm{~g} /$ day of betaine supplementation leads to an increase in plasma betaine (from $25.6 \pm 9.6$ at day 0 to $187.3 \pm 107.8$ at 6 months), plasma DMG (from $15.8 \pm 3.3$ at day 0 to $51.8 \pm 55.6$ at 6 months) and urine betaine (from $82 \pm 52.6$ day 0 to $954.1 \pm 1,186.8$ at 6 months) concentrations ( $\mu \mathrm{mol} / \mathrm{L}$ ) as compared to the placebo group (betaine and DMG plasma concentrations were statistically significantly different between groups; $p<0.001$ ).

Another study (unpublished study report, undated) reported an increase in plasma and urine betaine concentrations (plasma betaine: from $31.4 \pm 9.5$ at day 0 to $168.8 \pm 100.2$ at week 12; urine betaine: from $145.8 \pm 82.0$ at week 0 to $993.0 \pm 1,083.0$ at week 12) and plasma DMG (from $5.1 \pm 0.9$ at week 0 to $28.8 \pm 30.7$ at week 12$)$ concentrations $(\mu \mathrm{mol} / \mathrm{L})$ in subjects who received $4 \mathrm{~g} /$ day of betaine for 12 weeks as compared to the placebo group (plasma betaine and DMG concentrations were statistically significantly different between groups; $\mathrm{p}<0.001$ ).

After 12 weeks of betaine supplementation ( $3 \mathrm{~g} /$ day), Tiihonen et al. (2016) reported that betaine plasma concentrations were higher in the betaine group as compared to the placebo group $(132.7 \pm 52.7$ vs $47.7 \pm 9.8 \mu \mathrm{mol} / \mathrm{L}$, respectively; $\mathrm{p}<0.005)$.

The available data indicate that, following oral ingestion, betaine is rapidly absorbed, released to the portal circulation and transported to the liver where significant presystemic metabolism occurs. Only a small amount of betaine and its metabolite DMG are excreted in the urine.

\subsubsection{Genotoxicity}

The applicant provided a series of genotoxicity studies on the NF (betaine monohydrate; > 99\% purity), which were assessed by the Panel in 2005 (EFSA, 2005): a bacterial reverse mutation test using Salmonella Typhimurium, an in vitro mammalian chromosome aberration test using human lymphocytes and an in vivo bone marrow micronucleus test using mice (Unpublished study reports, $1989 a, b, c)$. These studies were conducted in compliance with the Organisation for Economic Co-operation and Development (OECD) principles of Good Laboratory Practice (GLP) (OECD, 1982).

No genotoxicity was observed in these studies.

Even though the genotoxicity testing strategy is not fully in line with current EFSA recommendations (EFSA Scientific Committee, 2011) as regards the in vitro mammalian micronucleus test, the Panel considers that there are no concerns with respect to genotoxicity of the NF. 


\subsubsection{Acute toxicity studies}

The acute oral toxicity study in rats (unpublished study report, 1990), which was conducted in compliance with the principles of GLP and in accordance with OECD Test Guideline No. 401 (OECD, 1987), has been previously assessed by the Panel (EFSA, 2005). The $L D_{50}$ was determined to be approximately $11 \mathrm{~g} / \mathrm{kg}$ bw.

\subsubsection{Repeated-dose toxicity studies}

\section{Subacute and subchronic toxicity studies}

The applicant referred to the 28-day and 90-day oral toxicity studies in Sprague-Dawley rats by TNO BIBRA (Unpublished study reports, 2001a,b) and by Hayes et al. (2003), which have been previously assessed by the Panel (EFSA, 2005). The studies by TNO BIBRA (Unpublished study report, 2001a,b) were conducted in compliance with the principles of GLP. Notwithstanding EFSA's request, no information was provided whether the study by Hayes et al. (2003) was conducted in compliance with GLP.

Upon EFSA's request for information on the test material used in these studies, the applicant provided the certificate of analysis, which indicates a purity of at least $99 \%$ (by high-performance liquid chromatography (HPLC)) of the test material (anhydrous betaine) and compliance with the specifications for the NF.

In 2005, the Panel concluded that results of animal studies do not prove satisfactorily that betaine is safe. Subacute and subchronic toxicity studies in Sprague-Dawley rats (i.e. Unpublished study reports, 2001a,b) have clearly shown that the liver is the main target organ in rats. The dose-related effects, more pronounced in females, included increased liver weight, hepatocellular vacuolisation and increased serum concentrations of liver enzymes. The changes were largely reversible. They were observed, however, at all tested dose levels, even after a short treatment period of 14 days. Therefore, a NOAEL could not be established. Another study (i.e. Hayes et al., 2003), in which betaine was given to female Sprague-Dawley rats and in which 'no apparent abnormalities of clinical importance' were reported, did not comply with OECD and GLP requirements for studies. As the available studies did not allow the derivation of a NOAEL for betaine and data on reproduction and developmental toxicity were lacking, an acceptable daily intake could not be established from the animal data (EFSA, 2005).

The applicant has now provided a tolerance study in piglets (unpublished study report, 2012), which has been previously evaluated by the EFSA FEEDAP Panel in the context of an application for authorisation of betaine (anhydrous) as a nutritional additive to be used in feed and water for drinking for all animal species (EFSA FEEDAP Panel, 2013).

In this study, betaine was administered to piglets at dose levels up to $20,000 \mathrm{mg} / \mathrm{kg}$ feed (which corresponds to $2 \%$ of betaine in the diet) for 6 weeks. Upon an EFSA request for information on the test material (anhydrous betaine), the applicant provided the certificate of analysis, which indicates a purity of $99 \%$ (by HPLC) and compliance with the specifications of the NF.

The FEEDAP Panel indicated that the only biologically relevant effects observed in this study were a dose-dependent decrease in serum phosphorus and increased hepatocellular vacuolisation in the highest betaine dose group ( $2 \%$ of betaine in the diet) as compared to the control group. The latter finding appears to be in agreement with the observation of the NDA Panel (EFSA, 2005) that subacute and subchronic toxicity studies have clearly shown that the liver is the main target organ in rats. However, the FEEDAP Panel noted that in the study in piglets, increased liver weight and increased liver enzymes were not observed.

The applicant has also referred to a 4-week study in rats, which was mentioned in a Scientific Discussion published by the European Medicines Agency (EMA) in the context of the evaluation of anhydrous betaine for use as a therapeutic agent in patients with homocystinuria (EMA, 2007). In this study, groups of 10 male and 10 female rats (strain not specified) were administered the test material in the diet at dose levels of 0 (control), 1.3 or $2.6 \mathrm{~g} / \mathrm{kg}$ bw per day for 29 days. According to EMA, the no-observed-effect level (NOEL)/NOAEL was $2.6 \mathrm{~g} / \mathrm{kg}$ bw per day, the highest dose tested.

In addition, the applicant has referred to several repeated-dose studies in mice and rats, which have not been included in the previous application of betaine (Barak et al., 1993, 1994; Kim and Kim, 2002, 2005; Balkan et al., 2005; Schwahn et al., 2007; Wang et al., 2010; Okada et al., 2011). In these studies, betaine was administered at doses between 300 and $3,770 \mathrm{mg} / \mathrm{kg}$ bw per day to different strains of mice or rats, for periods between 2 weeks and 1 year. The studies were designed to assess the effects of betaine in ameliorating certain disease states, particularly of the liver. 
Compared with the relevant toxicological studies described in previous paragraphs, group sizes were smaller and a limited number of endpoints were examined. The Panel thus concludes that these additional studies do not add relevant information to the risk assessment of the NF.

\section{Chronic toxicity and carcinogenicity studies}

When betaine was first evaluated by the NDA Panel in 2005 (EFSA, 2005), long-term toxicity studies were not available. The applicant has now provided a chronic oral toxicity and carcinogenicity study in F344/DuCrj rats (unpublished study report, 2002). No GLP certificate was provided and no reference was made to any national or international guidelines followed. The Panel notes, however, that the design of the study was similar to that recommended in OECD TG 453 for combined chronic toxicity/carcinogenicity studies (OECD, 2009). In the chronic part of the study, groups of 10 males and 10 females (individually housed) were provided a standard rodent diet containing $0.0 \%$ (control), $1.0 \%$ (low dose), $2.3 \%$ (mid dose) or $5.0 \%$ (high dose) of the NF (purity $99.9 \%$ ) for 52 weeks. The average betaine intake was determined to be 426,975 and $2,104 \mathrm{mg} / \mathrm{kg}$ bw per day in males of the low-, mid- and high-dose groups, respectively, and 515, 1,142, and 2,442 mg/kg bw per day in females of the low-, mid- and high-dose groups, respectively. In the carcinogenicity part, groups of 50 male and 50 female rats (individually housed) were administered diets containing $0 \%$ (control), $1 \%$ (low dose) or $5 \%$ (high dose) betaine for 104 weeks. In this study the average betaine intake was determined to be 378 and $1,802 \mathrm{mg} / \mathrm{kg}$ bw per day in males of the low- and high-dose groups, respectively, and 458 and $2,141 \mathrm{mg} / \mathrm{kg}$ bw per day in females of the low- and high-dose groups, respectively. Test and control diets, as well as water were provided throughout the study to ensure ad libitum feeding. Upon EFSA's request for information on the test material used in these studies, the applicant indicated that the test material (betaine, with $99.9 \%$ purity) was not produced by the applicant but by another Japanese company which followed the applicant's patented method.

In the chronic part of the study, all animals survived the treatment period and no treatment-related changes in animal performance were identified. Body weights of female rats of the high-dose group were statistically significantly lower compared with the control group at weeks 4, 5 and 10, but final body weights did not differ. Feed intake of males and females in all groups was significantly lower than in the control group during different time periods; in females, there was a weak correlation to dose and body weight. Haematology and clinical chemistry analyses were conducted only at the end of the treatment period. Mean corpuscular volume (MCV) was lower (dose-related) in males (mid- and high-dose group) and females (all three test groups) as compared with the control group. In males and females of the high-dose group, mean corpuscular haemoglobin (MCH) was significantly lower. Males of all test groups showed a significantly higher platelet count (dose-related), and a trend is also noted in females. Total protein plasma concentrations were significantly reduced in the high-dose group (both sexes), albumin plasma concentrations were lower in the high-dose group (both sexes) and females of the mid-dose group, and the albumin/globulin ratio was lower in males (all three test groups) and females (mid- and high-dose group). Males showed significant and dose-related reductions in the activities of alkaline phosphatase (ALP) (mid- and high-dose group), alanine transaminase (ALT) and aspartate transaminase (AST) (all test groups). In females, only AST was significantly reduced in the high-dose group, but ALP and ALT activities showed a trend in this direction. As compared to control groups, the activity of $\gamma$-glutamyltransferase was significantly lower in males but higher in females (both in the mid- and highdose groups). Females also showed lower concentrations of bilirubin (mid- and high-dose group) and calcium (high-dose group). Urinalysis was not conducted. Organ weight determinations at necropsy showed a significantly higher kidney weight in high-dose males (relative weight) and females (absolute and relative weight) and a higher liver weight in high-dose females (absolute and relative weight). Males of the low- and mid-dose groups showed a significantly lower relative heart weight. Females of the lowdose group showed a significantly lower absolute heart weight, whereas females of the mid-dose group showed a significantly lower relative heart weight. Macroscopic examinations revealed no treatmentrelated effects, and in the microscopic examinations of tissues the incidence and severity of histopathological changes was comparable in all groups.

In the carcinogenicity part of the study, there was no significant difference in the overall survival rate between betaine groups and the control group. The number of rats, which died or were killed in a moribund state, was 8 (control), 7 (1\% betaine) and 4 (5\% betaine) in males, and 6 (control), 11 (1\% betaine) and 7 (5\% betaine) in females. No treatment-related changes in animal performance were identified. Body weights of rats administered $5 \%$ betaine in the diet were statistically significantly lower compared with the control group in males at weeks $2-5$ and in females at weeks 2 and 3. At later time points, male rats of the low- and high-dose group showed significantly higher body weights 
(at weeks 21, 25, 29, 33, 37 and 41, and at weeks 21, 25, 33, 37, 49 and 97, respectively). Final body weights did not differ significantly from those of the control group. Feed intake in both test groups was significantly different compared with the control group during numerous time periods in males and females. Feed intake did not show a consistent correlation with dose and body weight.

Haematology analysis at the end of the treatment period showed significantly lower MCV and MCH in females of the high-dose group compared with the control group. Females of the low-dose group showed a significantly higher $\mathrm{MCH}$. Platelet counts were significantly higher in low- and high-dose males (dose-related) and high-dose females. Organ weight determinations at necropsy showed a significantly increased kidney weight in low-dose males (absolute weight), high-dose males (absolute and relative weight) and high-dose females (absolute weight). Liver weight was significantly increased in low-dose males (absolute weight), low-dose females (relative weight) and high-dose females (absolute and relative weight). Males of the low-dose group showed a higher absolute heart weight and females of the high-dose group a lower relative heart weight. Females of the high-dose group also had a higher absolute lung weight.

Macroscopic examinations revealed a higher number of females in the low- and high-dose group (dose-related) showing pale spots in the liver; there was also a slight increase in high-dose males. Microscopic examinations of tissues showed that the overall tumour incidence (number of cases and percentage) of males as well as females was comparable in the test groups and the control group (males: $49(98 \%)$ in all three groups; females: control $43(86 \%), 1 \%$ betaine $43(87.8 \%)$ and $5 \%$ betaine $40(80 \%))$. No statistically significant increase in the incidence of any tumour type was observed in both male and female animals of the high-dose group when compared with the control group. Nevertheless, regarding the liver, three low-dose males and four high-dose males as well as one high-dose female showed liver tumours (hepatocellular adenomas plus carcinomas). In this study, no tumours were identified in the control group; however, historical control data show that hepatocellular adenomas and carcinomas occur spontaneously in this strain of rats (Haseman et al., 1998; Ando et al., 2008). Regarding the kidneys, one male of the high-dose group showed a renal cell adenoma, and one female of the mid-dose group, which died during the treatment period, showed a nephroblastoma. The only significant differences identified (thyroid C-cell adenoma, adrenal gland pheochromocytoma, testis interstitial cell tumour, pituitary gland adenocarcinoma and uterus endometrial stromal polyp) related to decreases in tumour incidences and/or only occurred in the lowdose group. Other histopathological changes in these and other tissues occurred with similar incidence and severity in all treatment groups. The Panel considers that the tumours observed are not related to treatment with betaine and do not raise concern with regard to carcinogenicity of the NF.

The Panel notes that several of the changes in haematology and clinical chemistry parameters as well as in organ weights in the chronic part of the study had also been observed in the subchronic toxicity study by TNO BIBRA (Unpublished study report, 2001a,b), previously evaluated by EFSA (2005). Some of these changes were also seen in the carcinogenicity part after 104 weeks. Since an increase in platelet counts occurred in male rats already at the lowest dose level, the Panel considers that it is not possible to derive a NOAEL from this combined chronic toxicity/carcinogenicity study.

The Panel considered the dose-related increase in platelet counts in male rats as the critical effect and subjected the data from the 52-week chronic oral toxicity study to a benchmark dose (BMD) modelling, using the EFSA web-tool for BMD analysis, ${ }^{4}$ which is based on PROAST software. As indicated in the EFSA Guidance on the BMD approach (EFSA Scientific Committee, 2017), the benchmark response (BMR) default value of $5 \%$ has been used to calculate the $\mathrm{BMD}_{05}$. Confidence intervals $(90 \%)$ were estimated around the BMDs and the corresponding values for the upper and lower confidence limits (BMDUs and BMDLs, respectively) were calculated (BMD report available in Annex A).

The lowest $B M D L_{05}$ of $131 \mathrm{mg} / \mathrm{kg}$ bw is considered by the Panel as the reference point (RP) for the risk characterisation.

\subsubsection{Reproduction and developmental toxicity studies}

No reproduction or developmental toxicity studies on the NF conducted according to OECD guidelines were identified in the scientific literature.

The applicant has referred to a study, in which the betaine concentration in tissues of developing rats was examined (Clow et al., 2008). Betaine was administered to pregnant Sprague-Dawley rats

\footnotetext{
${ }^{4}$ https://efsa.openanalytics.eu/
} 
(5/group) via the diet at a level of $0 \%$ (control diet) or $0.3 \%$ from gestation day 5 to postnatal day 50. After weaning, pups were fed either the same diet as their mother or the alternative diet. While the betaine content of plasma, liver and kidneys increased in pups fed the betaine diet following weaning, the presence of betaine in the maternal diet had no effect on pup betaine content or on two enzymes of betaine metabolism. No significant difference in pup growth was observed between groups. No further safety-related endpoints were evaluated.

\subsubsection{Effects on glutathione homoeostasis}

A concern about potential effects of betaine on glutathione homoeostasis was addressed by the Panel in 2005 (EFSA, 2005). It had been suggested that an acute dose of betaine enhances metabolic reactions in the methionine cycle, but inhibits cystathionine and cysteine synthesis, leading to a decrease in supply of cysteine for glutathione synthesis in mice and rats (Kim et al., 2003).

The applicant has provided new data related to this issue.

Administration of betaine (1\%) in drinking water for up to 3 weeks to male ICR mice did not affect cysteine or glutathione levels in plasma, kidneys and liver (Kim and Kim, 2005).

After administration of betaine $(1.5 \%)$ in drinking water for 4 weeks, no changes in hepatic glutathione levels were observed in male Wistar rats (Balkan et al., 2005).

In a study with male Fischer 344 rats, betaine was administered in the diet at levels of $1 \%$ or $2 \%$ for 2 weeks. A statistically significant dose-related increase in hepatic glutathione levels compared with the control group was observed, while serum concentrations were significantly higher in the $1 \%$ betaine group and significantly lower in the $2 \%$ betaine group (Okada et al., 2011).

The Panel notes that these studies do not show a negative impact of betaine on glutathione levels.

\subsubsection{Human studies}

The applicant provided a number of human studies on betaine. Several studies in healthy subjects investigated the effect of betaine on plasma homocysteine concentrations (Brouwer et al., 2000; Olthof et al., 2003) or on physical exercise (Armstrong et al., 2008; Hoffman et al., 2009; Lee et al., 2010a; Trepanowski et al., 2011; del Favero et al., 2012; Pryor et al., 2012) at a single dose of $5 \mathrm{~g} /$ day (Armstrong et al., 2008), doses up to $2.5 \mathrm{~g} /$ day for periods up to 15 days (Hoffman et al., 2009; Lee et al., 2010a; Trepanowski et al., 2011; del Favero et al., 2012; Pryor et al., 2012) or at $6 \mathrm{~g} /$ day for 6 weeks (Brouwer et al., 2000; Olthof et al., 2003). These studies did not investigate safety-related endpoints, although one short-period study, in which 13 men received $2.5 \mathrm{~g}$ of betaine for 14 days, reported that no adverse effects were noted with either betaine or placebo supplementation and that treatment with betaine was well tolerated (Trepanowski et al., 2011).

The randomised, cross-over study by Atkinson et al. (2009) investigated blood lipids parameters in eight healthy males who consumed either a betaine-rich diet or a betaine supplement for 14 days. The Panel considers that no conclusion can be drawn from this uncontrolled study on the effect of betaine on blood lipids.

In a randomised, double-blind, placebo-controlled, cross-over study by Olthof et al. (2006) on the effect of supplementation with $6 \mathrm{~g}$ /day of betaine over a period of 6 weeks on flow-mediated dilatation in 39 healthy men and women, aged 50-70 years, adverse events were reported. A total of 112 nonserious adverse events (mainly headache and common cold/influenza), were noted in 31 participants. However, no details were provided on the number of the adverse events in the betaine or placebo group. The Panel considers that no conclusion can be drawn from this study on the safety of betaine.

The randomised, placebo-controlled, double-blind parallel study by Schwab et al. (2002) investigated effects of supplementation with $6 \mathrm{~g} /$ day of betaine over 12 weeks in 42 obese, but otherwise healthy white subjects (14 men, 25-60 years old, body mass index (BMI) $33.5 \pm 3.1 \mathrm{~kg} / \mathrm{m}^{2}$ ) treated with a lowenergy diet. No power calculation was reported. Body weight, resting energy expenditure, fat mass, diastolic blood pressure, fasting serum asparagine aminotransferase, alanine aminotransferase and $\gamma$-glutamyltransferase concentrations decreased in both groups without a significant difference between the groups. The fasting serum alkaline phosphatase concentration showed a tendency to increase in the control group but not in the betaine group. Plasma homocysteine concentrations decreased in the betaine group. There were no statistically significant differences between groups with regard to fasting plasma glucose, serum thyroid-stimulating hormone (TSH) or creatinine concentrations. No significant changes in serum total or lipoprotein lipid concentrations were found in either of the groups, but at the end of the intervention, serum total ( $5.5 \pm 1.1$ vs $4.9 \pm 0.6 \mathrm{mmol} / \mathrm{L})$ and low-density lipoprotein $(\mathrm{LDL})$-cholesterol $(3.7 \pm 1.0$ vs $3.0 \pm 0.5 \mathrm{mmol} / \mathrm{L})$ concentrations were higher in the betaine group 
than in the control group $(p<0.05)$. The adverse side effects monitored, through a self-reporting form included gastrointestinal illnesses, thirst, dry mouth, increased urination, and preference for salt or salty food. No adverse effects were systematically reported by the subjects in either of the groups.

Olthof et al. (2005) reported data on blood lipids that were combined post hoc from three individual (two parallel and one cross-over) placebo-controlled, randomised intervention studies in 151 healthy subjects (81 men, 30-70 years old) (Steenge et al., 2003; Olthof et al., 2003, 2006; see also Section 3.6). The primary outcome of the intervention studies was the effect of betaine supplementation of $6 \mathrm{~g} /$ day for 6 weeks on plasma homocysteine concentrations of healthy subjects selected for highest total plasma homocysteine concentrations. In two of the three studies, the increase in total- and LDL-cholesterol concentrations was significant. By combining the data from all three studies, the increase relative to placebo was $0.36 \mathrm{mmol} / \mathrm{L}(95 \% \mathrm{CI} 0.25-0.46)$ for LDLcholesterol and $0.14 \mathrm{mmol} / \mathrm{L}(95 \%$ CI $0.04-0.23)$ for triacylglycerol concentrations $(p<0.05)$. The ratio of total to high-density lipoprotein (HDL)-cholesterol increased by 0.23 ( $95 \%$ CI $0.14-0.32$ ) $(p<0.05)$ relative to placebo. Concentrations of HDL-cholesterol were not affected. Doses of betaine lower than $6 \mathrm{~g} /$ day ( 1.5 or $3 \mathrm{~g} /$ day) also raised LDL-cholesterol, but these changes were not statistically significant. The adverse events reported in the intervention studies were not serious and apparently related to methionine loading.

Another randomised, placebo-controlled, double-blind intervention study (Schwab et al., 2011; unpublished study report of the study, undated) investigated the effects of a 6-month intervention with $4 \mathrm{~g} /$ day of betaine (BetaPower ${ }^{\mathrm{rm}}$ ) on serum lipid profile among haematology and blood chemistry parameters in 63 healthy volunteers (13 men; $27 \pm 8$ years old; BMI $22.6 \pm 2.4 \mathrm{~kg} / \mathrm{m}^{2}$ ). No power calculation was reported. There were no statistically significant differences within or between groups with regard to body weight, BMI, systolic and diastolic blood pressure over the 24-week period. No statistically significant difference (within or between groups) was reported for platelet counts $\left(\times 10^{9} / \mathrm{L}\right)$ ( $284 \pm 68$ at week 0 and $272 \pm 65$ at week 24 in the betaine group; $278 \pm 56$ at week 0 and $262 \pm 52$ at week 24 in the control group). Plasma plasminogen activator inhibitor 1 (PAI-1) concentration increased in the betaine group (from $7.19 \pm 2.91$ at week 0 to $8.85 \pm 3.78 \mathrm{AU} / \mathrm{mL}$ at week 24; $p=0.028$ ) and decreased in the control group, resulting in a statistically significantly higher concentration in the betaine group than in the control group at the end of the study ( $8.85 \pm 3.78$ vs $6.25 \pm 2.38 \mathrm{AU} / \mathrm{mL}, \mathrm{p}=0.006$ ). Although increased PAI-1 concentration may slow down the fibrinolytic process, the levels of PAI-1 were within the normal range throughout the study. There were no statistically significant differences between and within groups in serum total cholesterol $(4.4 \pm 0.8$ at week 0 and $4.6 \pm 0.8$ at week 24 in the betaine group; $4.7 \pm 0.8$ at week 0 and $4.6 \pm 0.9$ at week 24 in the control group) and LDL-cholesterol $(2.64 \pm 0.70$ at week 0 and $2.74 \pm 0.65$ at week 24 in the betaine group; $2.63 \pm 0.72$ at week 0 and $2.61 \pm 0.74$ at week 24 in the control group) concentrations $(\mathrm{mmol} / \mathrm{L})$. There were no statistically significant differences between groups in the other parameters investigated which included haemostatic factors, other blood lipids parameters (e.g. HDL-cholesterol, triglycerides, oxidised LDL-cholesterol), plasma high-sensitivity C-reactive protein, blood haemoglobin, haematocrit and leucocytes; homocysteine, serum creatinine, $\gamma$-glutamyltransferase and alanine aminotransferase concentrations.

Another randomised, placebo-controlled, double-blind intervention study investigated the effects of a 3-month intervention with $4 \mathrm{~g} /$ day of betaine (BetaPower $^{\mathrm{TM}}$ ) on serum lipid profile among haematology and blood chemistry parameters in 32 individuals (18 men; mean age: 54-55 years; mean BMI: $29 \mathrm{~kg} / \mathrm{m}^{2}$ ) with metabolic syndrome according to the WHO criteria (unpublished study report of the study, undated). No power calculation was reported. No statistically significant differences (within or between groups) were reported in the parameters investigated except for serum total and LDL cholesterol, serum apolipoprotein B concentrations which increased in the betaine group (total cholesterol: from $5.7 \pm 0.8$ to $6.2 \pm 0.91 \mathrm{mmol} / \mathrm{L}$; LDL-cholesterol: from $3.74 \pm 0.71$ to $4.06 \pm 0.77 \mathrm{mmol} / \mathrm{L}$; serum apolipoprotein B: from $1.19 \pm 0.20$ to $1.30 \pm 0.25 \mathrm{~g} / \mathrm{L}$ ); plasma homocysteine concentration which decreased in the betaine group. No statistically significant difference (within or between groups) was reported in platelet counts $\left(\times 10^{9} / \mathrm{L}\right)(295 \pm 81$ at week 0 and $287 \pm 80$ at week 12 in the betaine group; $273 \pm 43$ at week 0 and $256 \pm 45$ at week 12 in the placebo group).

Upon an EFSA request for additional information, the applicant provided an ad hoc Expert report on platelet counts from a recently completed double-blind intervention study (unpublished study report, 2017). In this study, 75 male adults (mean age: $55-58$ years; mean BMI: $32.5-35.3 \mathrm{~kg} / \mathrm{m}^{2}$ ) with metabolic syndrome according to the International Diabetes Federation were randomised to receive either supplementation of betaine (BetaPower $\left.{ }^{\mathrm{TM}}\right)(0.5$ or $2.5 \mathrm{~g} /$ day) or placebo (maltodextrin) $(\mathrm{n}=25$ per group) for 6 months. Sample size was calculated based on the primary end-point of the study (i.e. 
change in body fat). There was no statistically significant difference over time (between or within groups) in platelet counts $\left(\times 10^{9} / \mathrm{L}\right.$ ) (in the high-betaine group: $244.2 \pm 55.0$ at week 0 and $251.6 \pm 63.8$ at week 24; in the low-betaine group: $236.9 \pm 51.5$ at week 0 and $228.1 \pm 50.5$ at week 24; in the placebo group: $217.2 \pm 67.7$ at week 0 and $219.0 \pm 68.8$ at week 24).

Upon an EFSA request for additional information, the applicant provided the publication of a double-blind intervention study in which 20 Japanese males (mean age: 43-46 years; mean BMI: $24-25 \mathrm{~kg} / \mathrm{m}^{2}$ ) with mild fatty liver (not requiring medication) were randomised to receive either supplementation of betaine $3 \mathrm{~g} /$ day (Betafin $\mathrm{BF}^{\circledR}$ ) or placebo (maltodextrin) ( $\mathrm{n}=10$ per group) for 12 weeks (Tiihonen et al., 2016). No power calculation was reported. Several parameters (e.g. liver fat content, liver enzyme activities and other markers of liver and kidney function, visceral and subcutaneous fat area, blood parameters) were investigated and adverse events were recorded throughout the study. Except for HDL-cholesterol concentration (which increased significantly in the betaine group but not in the placebo group) the authors did not report any statistically significant differences between groups in the parameters investigated including platelet counts $\left(\times 10^{9} / \mathrm{L}\right)$ (in the betaine group: $237.4 \pm 40.5$ at day 0 and $243.0 \pm 35.4$ at week 12 ; in the placebo group: $235.5 \pm 38.1$ at day 0 and $239.7 \pm 36.3$ at week 12 ), total cholesterol (in the betaine group: $5.76 \pm 0.97$ at day 0 and $6.32 \pm 0.8$ at week 12; in the placebo group: $5.79 \pm 0.81$ at day 0 and $5.93 \pm 0.69$ at week-12) and LDL-cholesterol (in the betaine group: $3.57 \pm 0.94$ at day 0 and $3.98 \pm 0.79$ at week 12 ; in the placebo group: $3.86 \pm 0.73$ at day 0 and $3.93 \pm 0.71$ at week 12) concentrations $(\mathrm{mmol} / \mathrm{L})$. No differences between groups in the frequency of adverse events were reported: five non-serious adverse events occurred in the betaine group and 12 non-serious adverse events occurred in the placebo group. The authors indicated that all events were mild and symptoms resolved without interruption of the intervention with the exception of one adverse event (loose stool) in the betaine group which could be related to the intervention.

The Panel notes that doses of $6 \mathrm{~g} /$ day of betaine for 12 weeks were reported to increase LDL- and total cholesterol concentrations in healthy obese subjects on a low-energy diet (Schwab et al., 2002) as well as in two of three studies providing $6 \mathrm{~g} /$ day of betaine for 6 weeks in healthy subjects selected for high plasma homocysteine concentrations (Olthof et al., 2005). A significant increase in total and $\mathrm{LDL}$-cholesterol concentrations ( 0.5 and $0.32 \mathrm{mmol} / \mathrm{L}$, respectively) was also seen in a study providing $4 \mathrm{~g} /$ day of betaine for 3 months in overweight subjects with metabolic syndrome (unpublished study report of the study, undated), but not in normal weight subjects receiving $4 \mathrm{~g} /$ day of betaine for 6 months (Schwab et al., 2011) or $3 \mathrm{~g} /$ day of betaine for 12 weeks (Tiihonen et al., 2016). The Panel considers that the results indicate that $4 \mathrm{~g} /$ day betaine and above may increase total and LDL-cholesterol concentrations (Schwab et al., 2002; Olthof et al., 2005; EFSA NDA Panel, 2011; unpublished study report of the study, undated).

The Panel notes that platelet counts were not statistically significantly different in subjects provided with $2.5,3$ or $4 \mathrm{~g}$ of betaine per day for 12 weeks up to 6 months from respective control groups (Schwab et al., 2011; unpublished study report, undated; Unpublished study report, 2017; Tiihonen et al., 2016) and that platelet counts over time in these studies were within normal ranges $\left(150-450 \times 10^{9} / \mathrm{L}\right)$.

Methyl donors such as betaine may promote methylation of DNA; whether an excess intake of methyl donors may be associated with altered DNA methylation and diseases is under discussion (Shorter et al., 2015). Changes in DNA methylation status are hypothesised to be involved in different stages of colorectal cancer (Ashktorab and Brim, 2014). No associations between dietary choline and betaine intake and risk of colorectal cancer were found in 47,302 men in the Health Professionals Follow-up Study from 1986 to 2004; however, absolute values of choline and betaine intakes were not provided (Lee et al., 2010b).

Betaine is a precursor of trimethylamine (TMA) formed by gut microbiota. TMA can either be oxidised to trimethylamine oxide (TMAO) by the gut microbiota or by human hepatic flavin monooxygenase 3. Increased TMAO levels have been associated with higher risk for adverse cardiac events and mortality in patients with chronic heart failure and in patients with type 2 diabetes mellitus (Trøseid et al., 2015; Tang et al., 2017).

The relationship between serum concentrations of TMAO and its precursors (choline, carnitine and betaine) and incident colorectal cancer risk was also investigated in a nested case-control study of male smokers in the Alpha-Tocopherol, Beta-Carotene Cancer Prevention (ATBC) Study (Guertin et al., 2017). Men with higher serum choline at baseline had approximately threefold greater risk of developing colorectal cancer over the ensuing $14 \pm 10$ years while the association between serum TMAO, carnitine or betaine and colorectal cancer risk was not statistically significant. 
The Panel considers that it is currently not possible to draw conclusions on potentially adverse consequences of the contribution of betaine to methylation-related processes and TMA-related processes.

\subsection{Allergenicity}

The NF is produced from sugar beet which is recognised not to be allergenic.

The production process may also include a fermentation step using the yeast $S$. cerevisiae, which is known to have allergenicity properties. In the specifications of the NF, the applicant has proposed a residual protein content of up to $1 \mathrm{mg} / \mathrm{g}$ for the NF.

The Panel notes that the risk of allergenicity for people who are allergic to yeast cannot be excluded.

\section{Discussion}

The NF which is the subject of the application is betaine, in anhydrous and monohydrate form, which is obtained from processing of sugar beets (i.e. molasses, vinasses or betaine glycerol). The information provided on the composition, the specifications, the batch-to-batch variability, stability and production process of the NF is sufficient and does not raise concerns about the safety of the NF.

The NF is proposed to be used in foods intended to meet additional requirements for intense muscular effort (i.e. carbohydrate-rich energy food products, carbohydrate-electrolyte solutions, and protein/protein components) with a proposed intake of $2.5 \mathrm{~g}$ betaine per day. The target population proposed by the applicant is sports people above 10 years of age (adolescents and adults).

Based on the proposed uses and maximum use levels and the food consumption data from the UK NDNS Rolling Survey Programme (2008-2011), the 95th percentile anticipated intake of the NF was calculated: $1.30 \mathrm{~g} /$ day $(26.4 \mathrm{mg} / \mathrm{kg}$ bw per day) for adolescents and $2.93 \mathrm{~g} / \mathrm{day}(35.7 \mathrm{mg} / \mathrm{kg}$ bw per day) for adults.

Betaine is naturally present in foods, such as beets, spinach and wheat flour. However, betaine exposure from the diet does not only derive from the consumption of betaine-containing foods but also from choline-containing foods as most choline is irreversibly oxidised to betaine in the body. The total exposure to betaine resulting from dietary intake calculated from the sum of highest reported mean intakes across studies can be estimated to be about $830 \mathrm{mg} /$ day.

The Panel considers that consumption of the NF is not nutritionally disadvantageous.

The Panel considers that the microbiological information provided does not raise safety concerns.

The Panel notes that the risk of allergenicity for people who are allergic to yeast, which can be used in the production process, cannot be excluded.

The available data indicate that, following oral ingestion, betaine is rapidly absorbed, released to the portal circulation and transported to the liver where significant presystemic metabolism occurs. Only a small amount of betaine and its metabolite DMG are excreted in the urine.

The Panel considers that there is no concern with respect to genotoxicity of the NF.

Several repeated-dose oral toxicity studies with the NF in rodents and piglets have been provided by the applicant, some of which were assessed by the NDA Panel in 2005. At that time, the Panel could not derive a NOAEL for the NF from the 28-day and 90-day oral toxicity studies.

The applicant has now provided a chronic oral toxicity and carcinogenicity study with the NF. The Panel notes that several of the changes in haematology and clinical chemistry parameters as well as organ weight changes observed in this study were also seen in the 90-day toxicity study previously evaluated in 2005. Since an increase in platelet counts in male rats was observed, which is regarded as a critical effect, already occurred at the lowest dose level, the Panel considers that it is not possible to derive a NOAEL for this combined chronic toxicity/carcinogenicity study. Therefore, in order to derive an adequate RP, the Panel subjected the data on platelet counts in male rats from the chronic oral toxicity study to BMD modelling. The lowest $B M D L_{05}$ of $131 \mathrm{mg} / \mathrm{kg}$ bw was considered by the Panel as the RP for the risk characterisation. The ratio between this RP and the anticipated daily intake of the NF in adults and adolescents results in Margins of Exposure of 3.6 and 5, which are generally regarded as not sufficient.

However, the Panel notes that the total exposure to betaine resulting from dietary intake calculated from the sum of highest reported mean intakes across studies (about $830 \mathrm{mg} / \mathrm{day}$, i.e. $12 \mathrm{mg} / \mathrm{kg} \mathrm{bw}$

\footnotetext{
${ }^{5}$ By using mean bw of $70 \mathrm{~kg}$ for adults (EFSA Scientific Committee, 2012).
} 
per day for adults; $19 \mathrm{mg} / \mathrm{kg} \mathrm{bw}^{6}$ per day for adolescents aged $10-14$ years and $13 \mathrm{mg} / \mathrm{kg} \mathrm{bw}$ per day for adolescents aged 14-18 years) is not known to be associated with adverse effects.

Moreover, the Panel notes that four human intervention studies are available with exposure levels of $4 \mathrm{~g} /$ day of betaine supplementation (which corresponds to $57 \mathrm{mg} / \mathrm{kg} \mathrm{bw}^{5}$ per day for adults) for up to 6 months. In these studies, no adverse effects on platelet counts were noted. The Panel also notes that a significant increase in total and LDL-cholesterol concentrations have been reported at intakes of $4 \mathrm{~g} /$ day of betaine in overweight subjects with metabolic syndrome but not in healthy subjects, nor at intakes of $3 \mathrm{~g} /$ day. In this context, the Panel considers that $4 \mathrm{~g} /$ day of betaine can be taken as a RP and that an uncertainty factor of 10 is sufficient to account for inter-individual variability (EFSA Scientific Committee, 2012). Therefore, an amount of $400 \mathrm{mg} /$ day of betaine (i.e. $6 \mathrm{mg} / \mathrm{kg} \mathrm{bw}^{5}$ per day for adults) in addition to the background exposure is considered as safe.

\section{Conclusions}

The Panel concludes that the safety of the NF, betaine, at the intended uses and use levels as proposed by the applicant ( $2.5 \mathrm{~g} /$ day) has not been established.

The Panel considers that the NF is safe to be used at maximum intake of $6 \mathrm{mg} / \mathrm{kg}$ bw per day in the target population (sports people above 10 years of age) in addition to the background exposure.

\section{Steps taken by EFSA}

1) Letter from the European Commission to the European Food Safety Authority with the request for a scientific opinion on the safety of betaine. Letter SANTE/E2/SS/ks D(2016) 1592858 - Ref. Ares(2016)1594324, dated 4 April 2016.

2) On 14 April 2016 EFSA received the following documentation: technical dossier 'request for authorisation of betaine', which was submitted by DuPont Nutritional Biosciences ApS; initial assessment report carried out by the Food Safety Authority of Finland: 'application concerning betaine as a novel food ingredient'; Member States' comments and objections; response by the applicant to the initial assessment report.

3) Upon a request by EFSA for missing information, on 7 June 2016, EFSA received the missing information as submitted by the applicant.

4) Additional data were provided by the applicant on $17 / 2 / 2017$ and on 20/9/2017.

5) During its meeting on 25 October 2017, the NDA Panel, having evaluated the data, adopted a scientific opinion on the safety of betaine as a novel food pursuant to Regulation (EC) No $258 / 97$.

\section{References}

Ando R, Nakamura A, Nagatani M, Yamakawa S, Ohira T, Takagi M, Matsushima K, Aoki A, Fujita Y and Tamura K, 2008. Comparison of past and recent historical control data in relation to spontaneous tumors during carcinogenicity testing in Fischer 344 rats. Journal of Toxicologic Pathology, 21, 53-60.

Anestad SE, Hauge B, Bjerck M and Schjøll A, 2009. Sports Nutrition Products. A Nordic consumer study. (TemaNord, 2009: 531). Nordic Council of Ministers, Copenhagen, Denmark. Available online: http://www. norden.org/da/publikationer/publikationer/2009-531

Armstrong LE, Casa DJ, Roti MW, Lee EC, Craig SA, Sutherland JW, Fiala KA and Maresh CM, 2008. Influence of betaine consumption on strenuous running and sprinting in a hot environment. Journal of Strength and Conditioning Research, 22, 851-860.

Ashktorab H and Brim H, 2014. DNA methylation and colorectal cancer. Current Colorectal Cancer Reports, 10, 425-430.

Atkinson W, Slow S, Elmslie J, Lever M, Chambers ST and George PM, 2009. Dietary and supplementary betaine: effects on betaine and homocysteine concentrations in males. Nutrition, Metabolism and Cardiovascular Diseases, 19, 767-773.

Balkan J, Parldar FH, Dogru-Abbasoglu S, Aykac-Toker G and Uysal M, 2005. The effect of taurine or betaine pretreatment on hepatotoxicity and prooxidant status induced by lipopolysaccharide treatment in the liver of rats. European Journal of Gastroenterology and Hepatology, 17, 917-921.

Barak AJ, Beckenhauer HC, Junnila M and Tuma DJ, 1993. Dietary betaine promotes generation of hepatic S-adenosylmethionine and protects the liver from ethanol-induced fatty infiltration. Alcoholism, Clinical and Experimental Research, 17, 552-555.

\footnotetext{
${ }^{6}$ By using mean bw of $43.4 \mathrm{~kg}$ for adolescents aged $10-14$ years (EFSA Scientific Committee, 2012).

7 By using mean bw of $61.3 \mathrm{~kg}$ for adolescents aged 14-18 years (EFSA Scientific Committee, 2012).
} 
Barak AJ, Beckenhauer HC and Tuma DJ, 1994. S-adenosylmethionine generation and prevention of alcoholic fatty liver by betaine. Alcohol, 11, 501-503.

Brouwer IA, Verhoef $P$ and Urgert $R, 2000$. Betaine supplementation and plasma homocysteine in healthy volunteers. Archives of Internal Medicine, 160, 2546-2547.

CFIA (Canadian Food Inspection Agency), 2012. The Biology of Beta vulgaris L. (Sugar Beet): biology document BIO2002-01: a companion document to Directive 94-08 (Dir94-08), Assessment Criteria for Determining Environmental Safety of Plant with Novel Traits. Available online: http://www.inspection.gc.ca/plants/plants-withnovel-traits/applicants/directive-94-08/biology-documents/beta-vulgaris-l-/eng/1330725373948/1330725437349 [Accessed: 2 March 2012]

Chu DM, Wahlqvist ML, Chang HY, Yeh NH and Lee MS, 2012. Choline and betaine food sources and intakes in Taiwanese. Asia Pacific Journal of Clinical Nutrition, 21, 547-557.

Clow KA, Treberg JR, Brosnan ME and Brosnan JT, 2008. Elevated tissue betaine contents in developing rats are due to dietary betaine, not to synthesis. Journal of Nutrition, 138, 1641-1646.

Craig SAS, 2004. Betaine in human nutrition. American Journal of Clinical Nutrition, 80, 539-549.

Dalmeijer GW, Olthof MR, Verhoef P, Bots ML and van der Schouw YT, 2008. Prospective study on dietary intakes of folate, betaine, and choline and cardiovascular disease risk in women. European Journal of Clinical Nutrition, $62,386-394$.

Deerr N, 1950. The beet and beet sugar (Chapter XXIX). The History of Sugar. Vol 2. Chapman and Hall Ltd., London, England. pp. 471-500.

Detopoulou P, Panagiotakos DB, Antonopoulou S, Pitsavos C and Stefanadis C, 2008. Dietary choline and betaine intakes in relation to concentrations of inflammatory markers in healthy adults: the ATTICA study. American Journal of Clinical Nutrition, 87, 424-430.

EFSA (European Food Safety Authority), 2005. Opinion of the Scientific Panel on Dietetic Products, Nutrition and Allergies on a request from the Commission related to an application concerning the use of betaine as a novel food in the EU. EFSA Journal 2005;3(3):191, 17 pp. https://doi.org/10.2903/j.efsa.2005.191

EFSA FEEDAP Panel (EFSA Panel on Additives and Products or Substances used in Animal Feed), 2013. Scientific Opinion on the safety and efficacy of betaine anhydrous as a feed additive for all animal species based on a dossier submitted by Danisco Animal Nutrition. EFSA Journal 2013;11(5):3209, 20 pp. https://doi.org/10.2903/ j.efsa.2013.3209

EFSA NDA Panel (EFSA Panel on Dietetic Products, Nutrition and Allergies), 2011. Scientific Opinion on the substantiation of health claims related to betaine and contribution to normal homocysteine metabolism (ID 4325) pursuant to Article 13(1) of Regulation (EC) No 1924/2006. EFSA Journal 2011;9(4):2052, 14 pp. https://doi.org/10.2903/j.efsa.2011.2052

EFSA NDA Panel (EFSA Panel on Dietetic Products, Nutrition and Allergies), 2016. Scientific opinion on Dietary Reference Values for choline. EFSA Journal 2016;14(8):4484, 70 pp. https://doi.org/10.2903/j.efsa.2016.4484

EFSA Scientific Committee, 2011. Scientific Opinion on genotoxicity testing strategies applicable to food and feed safety assessment. EFSA Journal 2011;9(9):2379, 69 pp. https://doi.org/10.2903/j.efsa.2011.2379

EFSA Scientific Committee, 2012. Guidance on selected default values to be used by the EFSA Scientific Committee, Scientific Panels and Units in the absence of actual measured data. EFSA Journal 2012;10(3):2579, 32 pp. https://doi.org/10.2903/j.efsa.2012.2579

EFSA Scientific Committee, 2017. Update: guidance on the use of the benchmark dose approach in risk assessment. EFSA Journal 2017;15(1):4658, 41 pp. https://doi.org/10.2903/j.efsa.2017.4658

EMA (European Medicines Agency), 2007. Scientific discussion on cystadane. European Agency for the Evaluation of Medicinal Products. Available online: http://www.ema.europa.eu/docs/en_GB/document_library/EPAR_-_Scie ntific_Discussion/human/000678/WC500037401.pdf

FAO (Food and Agriculture Organization of the United Nations), 1994. Sugar crops and sweeteners. In: Definition and Classification of Commodities (Draft) 3. Sugar Crops and Sweeteners and Derived Products. Available online: http://www.fao.org/es/faodef/fdef03e.HTM\#3.03

FAO (Food and Agriculture Organization of the United Nations), 2013. Crop Water Information: Sugarbeet. Water Management and Development Unit, Rome, Italy. Available online: http://www.fao.org/nr/water/ cropinfo_sugarbeet.html

FASEB (Federation of American Societies for Experimental Biology), 1981. Evaluation of the Health Aspects of Choline Chloride and Choline Bitartrate as Food Ingredients. (PB-223 845/9; SCOGS 42). Prepared by FASEB, Life Sciences Research Office (LSRO), Bethesda (MD) for U.S. Food and Drug Administration (U.S. FDA), Washington (DC).

del Favero S, Roschel H, Artioli G, Ugrinowitsch C, Tricoli V, Costa A, Barroso R, Negrelli AL, Otaduy MC, da Costa Leite C, Lancha-Junior AH and Gualano B, 2012. Creatine but not betaine supplementation increases muscle phosphorylcreatine content and strength performance. Amino Acids, 42, 2299-2305.

FCC (Food Chemicals Codex), 2014. Betaine. In: Food Chemicals Codex, 9th Edition. United States Pharmacopeial Convention (USP), Rockville, MD. pp. 140-141.

Fischer LM, Scearce JA, Mar MH, Patel JR, Blanchard RT, Macintosh BA, Busby MG and Zeisel SH, 2005. Ad libitum choline intake in healthy individuals meets or exceeds the proposed adequate intake level. Journal of Nutrition, $135,826-829$. 
Guertin KA, Li XS, Graubard BI, Albanes D, Weinstein SJ, Goedert JJ, Wang Z, Hazen SL and Sinha R, 2017. Serum trimethylamine $\mathrm{N}$-oxide, carnitine, choline and betaine in relation to colorectal cancer risk in the alpha tocopherol and beta carotene study. Cancer Epidemiology, Biomarkers and Prevention, 26, 945-952.

Haseman JK, Hailey JR and Morris RW, 1998. Spontaneous neoplasm incidences in Fischer 344 rats and B6C3F1 mice in two-year carcinogenicity studies: a National Toxicology Program update. Toxicologic Pathology, 26, 428-441.

Hayes KC, Pronczuk A, Cook MW and Robbins MC, 2003. Betaine in sub-acute and sub-chronic rat studies. Food and Chemical Toxicology, 41, 1685-1700.

Hoffman JR, Ratamess NA, Kang J, Rashti SL and Faigenbaum AD, 2009. Effect of betaine supplementation on power performance and fatigue. Journal of the International Society of Sports Nutrition, 6, 7.

Howe JC, Williams JR, Holden JM, Zeisel S and Mar M, 2004. USDA database for the choline content of common foods [Release One]. U.S. Department of Agriculture (USDA), Agricultural Research Service (ARS), Beltsville Human Nutrition Research Center, Nutrient Data Laboratory, Beltsville (MD).

Kim SK and Kim YC, 2002. Attenuation of bacterial lipopolysaccharide-induced hepatotoxicity by betaine or taurine in rats. Food and Chemical Toxicology, 40, 545-549.

Kim SK and Kim YC, 2005. Effects of betaine supplementation on hepatic metabolism of sulfur-containing amino acids in mice. Journal of Hepatology, 42, 907-913.

Kim SK, Choi KH and Kim YC, 2003. Effect of acute betaine administration on hepatic metabolism of S-amino acids in rats and mice. Biochemical Pharmacology, 65, 1565-1574.

Lee EC, Maresh CM, Kraemer WJ, Yamamoto LM, Hatfield DL, Bailey BL, Armstrong LE, Volek JS, McDermott BP and Craig SA, 2010a. Ergogenic effects of betaine supplementation on strength and power performance. Journal of the International Society of Sports Nutrition, 7, 27.

Lee JE, Giovannucci E, Fuchs CS, Willett WC, Zeisel SH and Cho E, 2010b. Choline and betaine intake and the risk of colorectal cancer in men. Cancer Epidemiology, Biomarkers and Prevention, 19, 884-887.

Mygind VL, Evans SE, Peddie MC, Miller JC and Houghton LA, 2013. Estimation of usual intake and food sources of choline and betaine in New Zealand reproductive age women. Asia Pacific Journal of Clinical Nutrition, 22, 319-324.

NDNS (National Diet and Nutrition Survey), 2012. National Diet and Nutrition Survey: headline results from years 1, 2 and 3 (combined) of the Rolling Programme 2008/09-2010/11. Available online: https://www.gov. uk/government/statistics/national-diet-and-nutrition-survey-headline-results-from-years-1-2-and-3-combined-ofthe-rolling-programme-200809-201011

OECD (Organisation for Economic Co-operation and Development), 1982. OECD Series on Principles of Good Laboratory Practice and Compliance Monitoring.

OECD (Organisation for Economic Co-operation and Development), 1987. Test No. 401: acute oral toxicity. In: OECD guideline for testing of chemicals, Section 4: Health effects, $7 \mathrm{pp}$.

OECD (Organisation for Economic Co-operation and Development), 2009. Test No. 453: combined chronic toxicity/carcinogenicity studies. In: OECD guidelines for the testing of chemicals, Section 4: Health effects, 20 pp.

Okada T, Kawakami S, Nakamura Y, Han KH, Ohba K, Aritsuka T, Uchino H, Shimada K, Sekikawa M, Ishii H and Fukushima M, 2011. Amelioration of D-galactosamine-induced acute liver injury in rats by dietary supplementation with betaine derived from sugar beet molasses. Bioscience, Biotechnology, and Biochemistry, $75,1335-1341$.

Olthof MR, van Vliet T, Boelsma $E$ and Verhoef $P, 2003$. Low dose betaine supplementation leads to immediate and long term lowering of plasma homocysteine in healthy men and women. Journal of Nutrition, 133, 4135-4138.

Olthof MR, van Vliet T, Verhoef P, Zock PL and Katan MB, 2005. Effect of homocysteine-lowering nutrients on blood lipids: results from four randomised, placebo-controlled studies in healthy humans. PLoS Medicine, 2, e135.

Olthof MR, Bots ML, Katan MB and Verhoef P, 2006. Effect of folic acid and betaine supplementation on flowmediated dilation: a randomized, controlled study in healthy volunteers. PLoS Clinical Trials, 1, e10.

Patterson KY, Bhagwat SA, Williams JR, Howe JC and Holden JM, 2008. USDA Database for the Choline Content of Common Foods: Release Two. U.S. Department of Agriculture (USDA), Agricultural Research Service (ARS), Beltsville Human Nutrition Research Center, Nutrient Data Laboratory, Beltsville (MD).

Price RK, Keaveney EM, Hamill LL, Wallace JM, Ward M, Ueland PM, McNulty H, Strain JJ, Parker MJ and Welch RW, 2010. Consumption of wheat aleurone-rich foods increases fasting plasma betaine and modestly decreases fasting homocysteine and LDL-cholesterol in adults. Journal of Nutrition, 140, 2153-2157.

Pryor JL, Craig SA and Swensen T, 2012. Effect of betaine supplementation on cycling sprint performance. Journal of the International Society of Sports Nutrition, 9, 12.

Ross $A B$, Zangger $A$ and Guiraud SP, 2014. Cereal foods are the major source of betaine in the Western dietanalysis of betaine and free choline in cereal foods and updated assessments of betaine intake. Food Chemistry, 145, 859-865.

SCF (Scientific Committee on Food), 2001. Report of the Scientific Committee on Food on composition and specification of food intended to meet the expenditure of intense muscular effort, especially for sportsmen. Available online: https://ec.europa.eu/food/sites/food/files/safety/docs/sci-com_scf_out64_en.pdf

Schjøll A, Bjerck M, Jacobse E and Anestad SE, 2009. The Nordic market for sports nutrition products. A market analysis using Norway as case. (TemaNord, 2009: 530). Nordic Council of Ministers, Copenhagen, Denmark. 
Schwab U, Torronen A, Toppinen L, Alfthan G, Saarinen M, Aro A and Uusitupa M, 2002. Betaine supplementation decreases plasma homocysteine concentrations but does not affect body weight, body composition, or resting energy expenditure in human subjects. American Journal of Clinical Nutrition, 76, 961-967.

Schwab U, Torronen A, Meririnne E, Saarinen M, Alfthan G, Aro A and Uusitupa M, 2006. Orally administered betaine has an acute and dose-dependent effect on serum betaine and plasma homocysteine concentrations in healthy humans. Journal of Nutrition, 136, 34-38.

Schwab U, Alfthan G, Aro A and Uusitupa M, 2011. Long-term effect of betaine on risk factors associated with the metabolic syndrome in healthy subjects. European Journal of Clinical Nutrition, 65, 70-76.

Schwahn BC, Hafner D, Hohlfeld T, Balkenhol N, Laryea MD and Wendel U, 2003. Pharmacokinetics of oral betaine in healthy subjects and patients with homocystinuria. British Journal of Clinical Pharmacology, 55, 6-13.

Schwahn BC, Wang XL, Mikael LG, Wu Q, Cohn J, Jiang H, Maclean KN and Rozen R, 2007. Betaine supplementation improves the atherogenic risk factor profile in a transgenic mouse model of hyperhomocysteinemia. Atherosclerosis, 195, e100-e107.

Shaw GM, Carmichael SL, Yang W, Selvin S and Schaffer DM, 2004. Periconceptional dietary intake of choline and betaine and neural tube defects in offspring. American Journal of Epidemiology, 160, 102-109.

Shorter KR, Felder MR and Vrana PB, 2015. Consequences of dietary methyl donor supplements: is more always better? Progress in Biophysics and Molecular Biology, 118, 14-20.

Steenge GR, Verhoef P and Katan MB, 2003. Betaine supplementation lowers plasma homocysteine in healthy men and women. Journal of Nutrition, 133, 1291-1295.

Storch KJ, Wagner DA and Young VR, 1991. Methionine kinetics in adult men: effects of dietary betaine on L-[2H3methyl-1-13C]methionine. American Journal of Clinical Nutrition, 54, 386-394.

Tang WH, Wang Z, Li XS, Fan Y, Li DS, Wu Y and Hazen SL, 2017. Increased trimethylamine N-oxide portends high mortality risk independent of glycemic control in patients with type 2 diabetes mellitus. Clinical Chemistry, 63, 297-306.

Tiihonen K, Saarinen MT, Alhoniemi E, Mitsuya N and Yamaki G, 2016. Effect of dietary betaine on metabolic syndrome risk factors in Asian males with mild fatty liver. Journal of Diabetes and Metabolism, 7, 692. https:// doi.org/10.4172/2155-6156.1000692

TNO BIBRA, unpublished study report, 2001a. A 14-day Range Finding Study and a 90-day Sub-chronic study in the rat with betaine. (TNO BIBRA final report no 4013/1/2/2001).

TNO BIBRA, unpublished study report, 2001b. A 28-day Sub Acute Toxicity and Reversibility Study in the Rat with Betaine. (TNO BIBRA final report no 4099/1/2/2001).

Trepanowski JF, Farney TM, McCarthy CG, Schilling BK, Craig SA and Bloomer RJ, 2011. The effects of chronic betaine supplementation on exercise performance, skeletal muscle oxygen saturation and associated biochemical parameters in resistance trained men. Journal of Strength and Conditioning Research, 25, 3461-3471.

Trøseid M, Ueland T, Hov JR, Svardal A, Gregersen I, Dahl CP, Aakhus S, Gude E, Bjorndal B, Halvorsen B, Karlsen TH, Aukrust P, Gullestad L, Berge RK and Yndestad A, 2015. Microbiota-dependent metabolite trimethylamine$\mathrm{N}$-oxide is associated with disease severity and survival of patients with chronic heart failure. Journal of Internal Medicine, 277, 717-726.

Unpublished study report, 1989a. Bacterial reverse mutation assay: betaine monohydrate. (Toxicol Study No: M/ AMES/17027).

Unpublished study report, 1989b. Metaphase analysis of human lymphocytes treated with betaine monohydrate. (Toxicol Study No: M/HL/17028).

Unpublished study report, 1989c. Mouse micronucleus test: betaine monohydrate. (Toxicol Study No: M/MMN/ 17029).

Unpublished study report, 1990. Betaine anhydrous: acute oral toxicity study in the rat (Report No: 90/CUT001/ 0359).

Unpublished study report, 2002. 52-Week chronic toxicity study and 104-week carcinogenicity study of betaine in rats. Protocol No.: Z-96-055 and Z-96-056.

Unpublished study report, 2012. Tolerance and efficacy of betaine in weaned piglets: final report. Unique trial code: PLI+D1380512.

Unpublished study report, 2017. Clinical study: effect of betaine supplementation on body composition in metabolic syndrome: satellite report on platelets.

Unpublished study report, undated. The effect of betaine on plasma homocysteine concentration, hemostatic factors and other risk factors associated with metabolic syndrome in middle-aged subjects and in healthy individuals without any risk factors.

USDA (US Department of Agriculture), 2010. What we eat in America: National Health and Nutrition Examination Survey (NHANES): 2007-2008. Available online: http://www.ars.usda.gov/Services/docs.htm?docid=18349

USDA (US Department of Agriculture), 2012. Nutrient intakes from food: mean amounts consumed per individual, by gender and age, what we eat in America, NHANES 2009-2010. Agricultural Research Service. Available online: http://www.ars.usda.gov/SP2UserFiles/Place/12355000/pdf/0910/Table_1_NIN_GEN_09.pdf

Vennemann FB, Ioannidou S, Valsta LM, Dumas C, Ocke MC, Mensink GB, Lindtner O, Virtanen SM, Tlustos C, D'Addezio L, Mattison I, Dubuisson C, Siksna I and Heraud F, 2015. Dietary intake and food sources of choline in European populations. British Journal of Nutrition, 114, 2046-2055. 
Wang Z, Yao T, Pini M, Zhou Z, Fantuzzi G and Song Z, 2010. Betaine improved adipose tissue function in mice fed a high-fat diet: a mechanism for hepatoprotective effect of betaine in nonalcoholic fatty liver disease. American Journal of Physiology Gastrointestinal and Liver Physiology, 298, G634-G642.

Zeisel SH, 1981. Dietary choline: biochemistry, physiology, and pharmacology. Annual Review of Nutrition, 1, 95-121.

Zeisel SH, Mar MH, Howe JC and Holden JM, 2003. Concentrations of choline-containing compounds and betaine in common foods. Journal of Nutrition, 133, 1302-1307.

Zeng FF, Xu CH, Liu YT, Fan YY, Lin XL, Lu YK, Zhang CX and Chen YM, 2014. Choline and betaine intakes are associated with reduced risk of nasopharyngeal carcinoma in adults: a case-control study. British Journal of Cancer, 110, 808-816.

Zhang CX, Pan MX, Li B, Wang L, Mo XF, Chen YM, Lin FY and Ho SC, 2013. Choline and betaine intake is inversely associated with breast cancer risk: a two-stage case-control study in China. Cancer Science, 104, 250-258.

\section{Abbreviations}

\begin{tabular}{|c|c|}
\hline ALP & alkaline phosphatase \\
\hline ALT & alanine transaminase \\
\hline AST & aspartate transaminase \\
\hline BMD & benchmark dose \\
\hline BMI & body mass index \\
\hline BMR & benchmark response \\
\hline bw & body weight \\
\hline CAS & Chemical Abstracts Service \\
\hline cfu & colony forming units \\
\hline DMG & dimethylglycine \\
\hline EMA & European Medicines Agency \\
\hline FAO & Food and Agriculture Organization of the United Nations \\
\hline GLP & Good Laboratory Practice \\
\hline GM & genetically modified \\
\hline HDL & high-density lipoprotein \\
\hline HPLC & high-performance liquid chromatography \\
\hline HS-GC/MS & headspace gas chromatography/mass spectrometry \\
\hline ICP-MS & inductively coupled plasma mass spectrometry \\
\hline ICUMSA & International Commission for Uniform Methods of Sugar Analysis \\
\hline LC/ESI-IDMS & liquid chromatography/electrospray ionisation-isotope dilution mass spectrometry \\
\hline $\mathrm{LD}_{50}$ & lethal dose, median \\
\hline LDL & low-density lipoprotein \\
\hline $\mathrm{MCH}$ & mean corpuscular haemoglobin \\
\hline MCV & mean corpuscular volume \\
\hline MS & Member State \\
\hline NDNS & National Diet and Nutrition Survey \\
\hline NF & novel food \\
\hline NOAEL & no-observed-adverse effect level \\
\hline NOEL & no-observed-effect level \\
\hline OECD & Organisation for Economic Co-operation and Development \\
\hline PAI-1 & plasma plasminogen activator inhibitor 1 \\
\hline PCB & polychlorinated biphenyls \\
\hline RP & reference point \\
\hline RTD & ready-to-drink \\
\hline SCF & Scientific Committee on Food \\
\hline TMA & trimethylamine \\
\hline TMAO & trimethylamine oxide \\
\hline TSH & thyroid-stimulating hormone \\
\hline USDA & United States Department of Agriculture \\
\hline WHO & World Health Organization \\
\hline
\end{tabular}




\section{Annex A - Benchmark Dose Modelling Report \\ Data description}

The endpoint to be analysed is: platelet counts in male F344/DuCrj rats from the 52-week chronic oral toxicity study (platelet_mean, $\mathrm{SD}=$ standard deviation, $\mathrm{n}=$ number of animals per group; Unpublished study report, 2002).

Data used for analysis:

\begin{tabular}{l|c|c|c}
\hline Dose & platelet_mean & SD & n \\
\hline 0 & 62.3 & 4.6 & 10 \\
\hline 426 & 68.9 & 6.2 & 10 \\
\hline 975 & 77.3 & 1.3 & 10 \\
\hline 2,104 & 78.8 & 3.2 & 10 \\
\hline
\end{tabular}

\section{Selection of the BMR}

The benchmark dose (BMD) is defined as the dose that corresponds with a $5 \%$ estimated change in response compared with the background response. The benchmark response (BMR) is the estimated response corresponding with the BMD of interest.

A $90 \%$ confidence interval around the BMD will be estimated, the lower bound is reported by BMDL and the upper bound by BMDU.

\section{Software used}

Results are obtained using the EFSA web-tool for BMD analysis. Fitting benchmark dose models is based on the R-package PROAST, version 64.9.

\section{Results}

Response variable: mean platelets counts.

\section{Fitted models}

\begin{tabular}{|c|c|c|c|c|}
\hline Model & Converged & loglik & npar & AIC \\
\hline Full & Yes & 56.50 & 5 & -103.00 \\
\hline m1- & Yes & 30.63 & 2 & -57.26 \\
\hline Expon. m3- & Yes & 53.36 & 4 & -98.72 \\
\hline Expon. m5- & Yes & 56.50 & 5 & -103.00 \\
\hline Hill m3- & Yes & 53.27 & 4 & -98.54 \\
\hline Hill m5- & Yes & 56.50 & 5 & -103.00 \\
\hline
\end{tabular}

\section{Estimated model parameters}

\section{EXP}

estimate for var- : 0.003472

estimate for a- : 62.13

estimate for CED- : 270.7

estimate for c- : 1.267

estimate for $\mathrm{d}-: 1.925$

HILL

estimate for var- : 0.003472

estimate for a- : 62.13

estimate for CED- : 311.9

estimate for c- : 1.269

estimate for $\mathrm{d}-: 3.278$ 


\section{Final BMD values}

\begin{tabular}{l|c|c|c}
\hline Model & BMDL & BMDU & BMD \\
\hline Expon. m5- & 131 & 403 & 270 \\
\hline Hill m5- & 158 & 409 & 310 \\
\hline
\end{tabular}

\section{Lowest BMDL and highest BMDU values}

\begin{tabular}{l|c|c}
\hline Subgroup & bmdl.lowest & bmdu.highest \\
\hline All & 131 & 409 \\
\hline
\end{tabular}

\section{Visualisation}
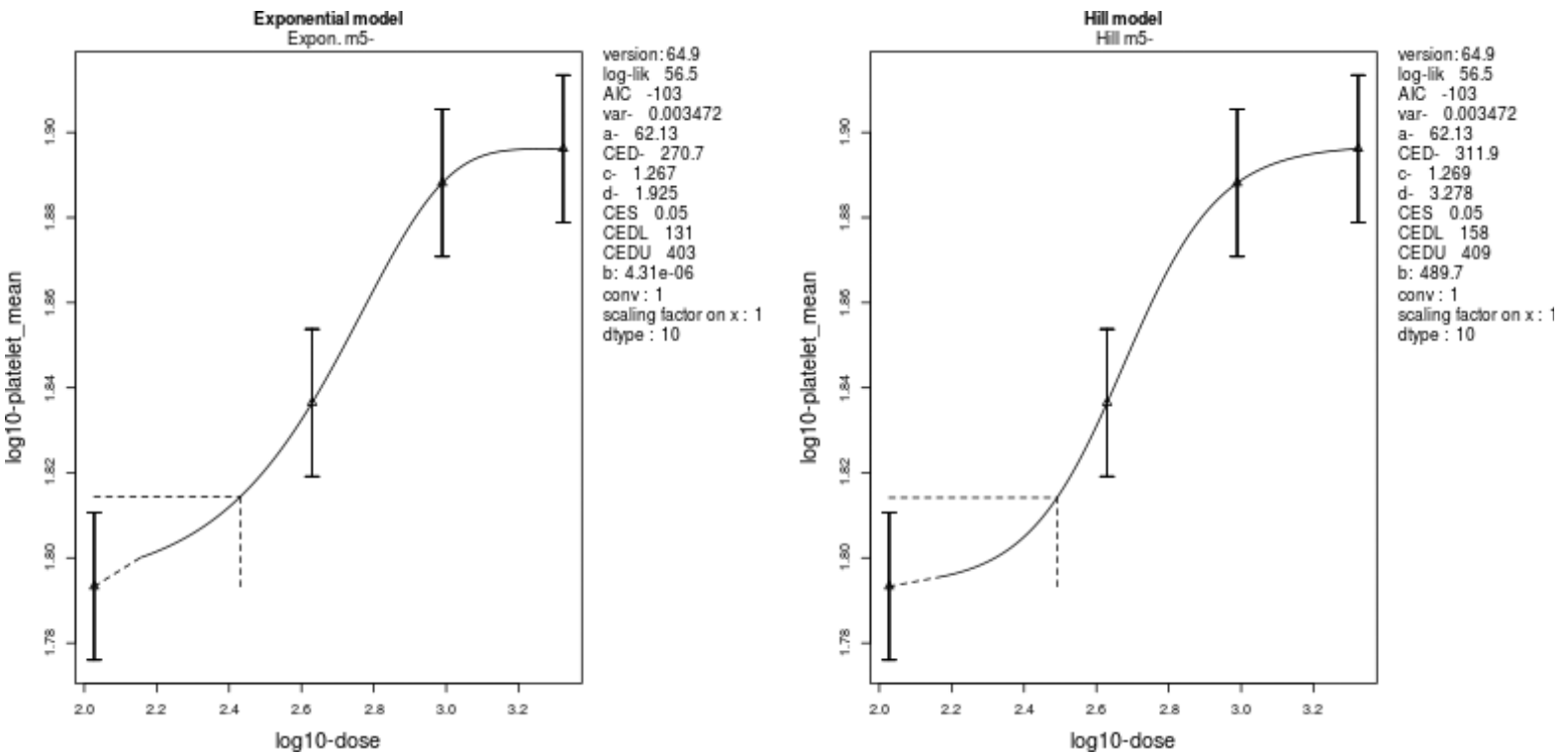

tactor on $x: 1$

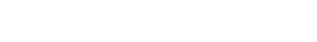

